\title{
TUZ, AŞİRET, DEVLET: SIIİT'TE TEKELİN OLUŞUMU, 1861-1881
}

\author{
Uğur Bayraktar*
}

\begin{abstract}
Öz
$\mathrm{Bu}$ makale Siirt sancağında Osmanlı tuz tekelini incelemektedir. Tekelin kuruluşu ve evrimine odaklanarak tekeli sancaktaki değişen sosyoekonomik dinamiklerin merkezinde ele almaktadır. Bu hâliyle, neredeyse tamamen Osmanlı Düyun-1 Umumiye İdaresi'nin kurulmasinı takip eden dönemin çalışıldığı literatüre yeni bir bakış açısı sunmaktadır. Tekelin tesisi öncesinde Kürt mirleri ve aşiretlerce işletilen Siirt'teki tuzlalar devir sırasında Osmanlı maliyesine ciddi bir darbe vurmuştur. Bu çalışma, özellikle Osmanlı tekelinin sancaktaki tuzlaları kontrol altına almak için başvurduğu yöntemlere odaklanarak tekelin gelişmesi için yürürlüğe giren hukuki gelişmeleri de göstermektedir. Aynı zamanda Osmanlı tekel memurlarının Kürt mirler ve aşiret ağalarıyla çok yönlü ilişkileri incelemektedir. Bu çalışmada bir yandan devlet ve aşiret ağalarının işbirliği yaptığı yerel çözümler öne çıkarılırken bir yandan da tüketimin vergilendirilebilir kılınmasının iktisadi sonuçlarına odaklanılmaktadır. Tuz fiyatlarındaki artışla doğrudan bir bağı olan tuz kaçakçılı̆̆ının karşısında bu çalışma bölgedeki artan devlet şiddetini göstermektedir. Bu makale, güvenlik ve kârlılık kaygılarıyla hareket eden Siirt'teki tuz tekelinin sancakta modern anlamda şiddet ve yoksulluk mefhumlarının görünür kıldığını iddia etmektedir.
\end{abstract}

Anahtar Kelimeler: Tekel, tuz, tuzla, aşiret, Siirt, Diyarbekir, yoksulluk

Salt, Tribe, and State: The Making of a Monopoly in Siirt, 1861-1881

\begin{abstract}
The present article is a study of Ottoman salt monopoly in the district of Siirt. It examines the establishment and evolution of the monopoly as a locus of the changing socioeconomic dynamics of the district. It offers a novel perspective to the literature on Ottoman monopolies, almost exclusively studied for the period following establishment of the Ottoman Public Debt Administration in 1881. Operated by the Kurdish emirs and
\end{abstract}

* Dr. Öğr. Üyesi, Ankara Sosyal Bilimler Üniversitesi Sosyal ve Beşeri Bilimler Fakültesi Tarih Bölümü, 06050, Hükümet Meydanı No: 2, Ulus-Ankara/Türkiye, ugur.bayraktar@asbu.edu.tr, Orcid ID: 0000-0001-8451-6271 


\section{Uğur Bayraktar}

tribes prior to the establishment of the monopoly, the salines in Siirt struck a severe blow to the Ottoman fisc during the takeover. By focusing particularly on the means the Ottoman monopolists developed for taking the salines in Siirt under control, it demonstrates the legal developments enforced for the improvement of the monopoly. It simultaneously explores the multifaceted relations the Ottoman monopoly officials established with the Kurdish emirs and tribal leaders. While highlighting the local solutions by which the both parties cooperated, it also deals with the economic consequence of fiscalising consumption. Salt smuggling due to increase in salt prices, this paper demonstrates, brought about an increasing degree of state violence in the district. The present study shows how the Ottoman salt monopoly in Siirt, driven with security and profitability concerns, rendered violence and poverty visible in the district.

Keywords: Monopoly, salt, saline, tribe, Siirt, Diyarbekir, poverty

\section{Giriş}

Osmanlı tarihçiliğinde gerek tuz gerekse de tekel çalışmaları oldukça az çalışılmış bir konu. Hem kaya hem de deniz tuzu açısından oldukça zengin kaynaklara sahip olan Osmanlı İmparatorluğu'nda tuzun hem iktisadi hem de toplumsal tarihi üzerine olan literatürdeki yoksunluk ancak son yillarda ortaya çıan çalışmalarla giderilmeye başlanmıştır demek yanlış olmaz. Aynı şekilde, Osmanlı İmparatorluğu'nun 19. yüzyllda geçirdiği mali buhran içinde tekel çalışmalarının neredeyse tamamıyla mali boyunduruk bağlamında ele alınan Düyun-1 Umumiye ile başlayan 1881 sonrası dönemle ilgilendiği belirtilmeli. Bu çalışmaların büyük çoğunluğu tütün tekeline odaklanmış ve Memalik-i Osmaniye Duhanları Müşterekül'l-Menfaa Reji Şirketi ya da kısaca Reji olarak bilinen Düyun-1 Umumiye şirketinin faaliyetlerini tütün kaçakçllı̆ı üzerinden ele almıstır. Bu sebeple, tuz ve tekel, Osmanlı tarihçiliğinde neredeyse birbirleriyle olan ilişkileri yokmuşçasına incelenegelmiştir. $\mathrm{Bu}$ duruma ek olarak bir de Osmanlı tarihçiliğinin doğu vilâyetlerine yönelik, iktisadi bir bakış açısından uzak ve büyük ölçüde siyasi saikler üzerine şsekillenmiş ilgisi de ortaya konduğunda, tuz üretiminde önemli merkezlerden biri olan Osmanlı İmparatorluğunun doğu vilayetlerinde tuz ve tekel tarihinin toplumsal ve iktisadi veçhelerine dair ciddi bir boşluk mevcut demek yanlış olmaz.

Bu çalışma, tuz ve tekel kavramlarını birlikte ele alarak, Diyarbekir vilayetine bağlı Siirt'te 1862'de kurulan tuz tekelinin oluşumunu ve gelişimini inceleyerek hem Osmanlı tarihçiliğine bir katkı sunmayı hem de tuz tekeli özelinde tekellerin Düyun-1 Umumiye öncesindeki dönemde ortaya çıkardığı toplumsal ve iktisadi dönüşümleri anlamlandırmayı amaçlamaktadır. Bu amaç doğrultusunda, bu çalışma öncelikle 19. yüzyıl öncesi ve Tanzimat dönemindeki tuz idaresinin genel hatlarına değinmekte ve özellikle 1862 Tuz Nizamnamesi ile sonlanacak tuz gelirlerinin idaresine yönelik Osmanlı yetkililerinin denedikleri ve tartıştıkları diğer yöntemleri ele almaktadır. Tuz tekeline giden süreç, ilkini Osmanlı Devleti'nin 1854'te aldığ1 
dış borçların devamındaki teminat arayışının bir parçasıydı. Tuz tekelini bu bağlamda Batı sermaye piyasalarına eklemlenmenin bir parçası olarak göstermeyi amaçlayan bu makale sonrasında Siirt'teki tuzlalar özelinde tuz tekelinin nasıl kurulduğu ve geliştiğini incelemektedir. Tekel bu sancakta içinde tuzla memurları, tuzlalarda hak iddia eden Kürt mirleri ve bu mirlerin güdümündeki aşiretler ve tuzlaların civarındaki köylerde yaşayan tuz işçilerinin bulunduğu girift biri yap1 içinde ortaya çıkmıştı. Bu makale, Siirt'te bu şekilde tesis edilen tekelin gelişimini Osmanlı hükümetinin çıkardığ1 yeni mevzuatlar ve Siirt özelinde gerçekleşen askeri yaptırımlar ve idari değişiklikler ile diyalog halinde incelemektedir. Kürt mirleri ve aşiretlerin tuz tekeline karşı gösterdiği direniş ve kaçakçıllk ile artan devlet şiddeti bağlamındaysa tuz kaçakçıları ve tuz işçilerinin hikâyeleri üzerinden tekelin farklı bir veçhe kazandırdığı yoksulluk mefhumun irdelemektedir.

Siirt tuzlalarının odağa alınmasının ardındaki öncelikli sebep olarak sıklıkla mültezimler veya devlet tarafindan işletilmiş tuzlalara nazaran buradaki çoğu tuzlanın aşiret beylerine tahsis edilmiş olması söylenebilir. Bu bağlamda, Kürt mir ve ağaların tuzlalar ile -mültezimlere nazaran- daha sıkı bir şekilde kurmuş oldukları düşünülen mülkiyet ilişkisinin tuzlaların devlete devri sonrasında ortaya çıkaracağ1 karmaşa, Osmanlı coğrafyasındaki birçok tuzladan daha farklı olabilecek sosyoekonomik dinamikleri ortaya çıkarması açısından önemlidir. Zira bir yandan 1830'larda başlamış 1840'ların ortasında son bulmuş olan Osmanlı hükümetinin Kürt mir ve beylerinin tasfiyesine yönelik siyasi ve askeri politikaları, öte yandan bu mir ve beylerce yurtluk-ocaklık ve hükümet şeklinde tasarruf edilmiş toprakların Osmanlı Maliyesi tarafindan zaptı ile 1860'lara kadar fiilen bu mir ve beylerce tasarruf edilmiş olması hayli muhtemel tuzlalar arasında kurulacak bağ bölgenin 19 . yüzyılda geçirdiği siyasi ve sosyoekonomik dönüşümüne yeni bir bakış açısı kazandirabilir.

Yakın zamanlardaki çalışmalarda tarihçilerin ikrar ettiği gibi, Osmanlı İmparatorluğu bağlamında herhangi sistematik bir çalışmadan yoksun olan tuz ve tuzla tarihindeki başlica çalışmalar erken modern dönemdeki tuzlaların idare ve örgütlenmesine odaklanmakta. ${ }^{1}$ Çoğunlukla kanunnamelere dayanan bu çalışmalar dağınık bir mahiyette de olsa Osmanlı tuzlalarına dair bilgi vermekteyken özellikle 2000 sonrasinda tuz ve tuzlalara dair sadece idare ve örgütlenmenin ötesinde daha toplumsal ve iktisadi konulara değinen çalışmalarda görece bir artıştan bahsedilebilir. ${ }^{2}$ Bu gelişmekte olan literatür, tuz ve tekel birlikte ele alındığında ise

1 Neșe Erim, "18. Yüzyılda Erzurum Tuzları: Osmanlı Tüketim Malları Tarihine Bir Katkı", A.Ü. Türkiyat Arastırmalarn Enstitüsü Dergisi, no. 21 (2003): 219-20; Evangelia Balta ve Fehmi Y1lmaz, "Salinas and Salt in Greek Lands during the Ottoman Period", Tuz Kitabı, ed. Emine Gürsoy Naskali ve Mesut Şen (İstanbul: Kitabevi Yayınları, 2004), 248.

2 Lütfi Güçer, "XV-XVII. Asırlarda Osmanlı İmparatorluğu'nda Tuz İnhisarı ve Tuzlaların İşletme Nizamı", İstanbul Üniversitesi İktisat Fakültesi Mecmuası 23, no. 1-2 (1962-1963); Ahmet Cihan, "Osmanlı Kanunnamelerinde Tuz ve Tuz Kültürü", Kamu Hukuku Arşivi Dergisi 5, no. 1 (2002). 


\section{Uğur Bayraktar}

yerini sadece son birkaç yılda yazılan yüksek lisans tezlerinin doldurmakta olduğu görece az çalışılan bir alana bırakmakta. ${ }^{3}$ Öte yandan, Osmanlı tekel çalışmalarına dönüldügünde ise bu alanın neredeyse tamamen tütüne hasredildiğini ve bu çalışmaların da 1881 sonrasında kurulan Düyun-1 Umumiye ve özellikle bu idareye bağlı kurulan Reji idaresine yönelik çalışmalar olduğu söylenebilir. ${ }^{4} \mathrm{Bu}$ çalışmalar bir yandan Bat1 sermayesinin Düyun-1 Umumiye'yi bir sömürgecilik arac1 olarak kullanarak Osmanlı maliyesinde ortaya çıkardığı dönüşümü ele alırken çoğunluğu da bu mali boyunduruğa karşı kurgulanmış kaçakçılık anlatısına odaklanmaktadır. ${ }^{5}$

Kuruluşu ve dönemi itibariyle Habsburg İmparatorluğu'ndaki Salzmonopol (Tuz Tekeli) ile bir tutulan Osmanlı tekeli bu modelden denizleri itibariyle daha Akdeniz benzeri ve daha az kitasal olmasiyla erken modern dönemdeki Venedik tuz idaresine benzetilmektedir. Osmanlı tuz tekeli, Fransızların ihtilâl öncesinde halkııın en çok başını ağnıtan dolaylı vergilerden biri olan tuz tekeli olan gabelle ile kıyaslandığında, Fransız tekelinin muaf bölgeleri karşısında daha toptancı bir tutumuyla daha kapsamlı idiyse de tuzun dolaylı vergi olarak değerlendirilmesi sürecinde Habsburg örneğine göre daha az kapsamlıdd1. ${ }^{6}$ Kurumsal iktisat açısından bakıldığında tekellerin, tuz tekelinin diş borçlara teminat olarak ortaya çıkması haricinde, Osmanlı ekonomisi açısından hem olumlu hem de olumsuz yanları söz konusuydu. Özel sermaye birikiminin kısıtlı olduğu yerde büyük sanayi yatırımları açısından tekellerin kurulması olumlu bir hasletken bu tekellerin sanayileşmedeki özel girişimlere ket vurmasının ekonomiye dayatacağı maliyetlerse olumsuzdu. ${ }^{7}$

Yine de tuz gibi zaruri bir metadan dolaylı vergi yaratarak bütçeye bir katkı sağlamak Osmanlı maliyesi için görece yeni bir oluşumdu. Osmanlı ekonomisinin temel ilkelerinden birinin iaşecilik olmasından hareketle, Genç devletin gerekli mal

2000 sonrasında önemli başlıca çalışmalar için bkz. Saim Savaş, "Osmanlı Döneminde Sivas'ta Tuz Üretimine Dair Bazı Bilgiler", Journal of Ottoman Studies no. 20 (2000); Fatmagül Demirel, "Osmanlı Devleti'nde Tuz Gelirlerinin Düyûn-1 Umûmiye'ye Devredilmesinden Sonra Tuz Kaçakçlığı", Yakın Dönem Türkiye Araștırmalar, no. 1 (2002); ed. Emine Gürsoy Naskali ve Mesut Şen, Tuz Kitabı (İstanbul: Kitabevi Yayınları, 2004).

3 Ekin Kasım, "Tuz Nizamnamesi Çerçevesinde 19. Yüzyılın İkinci Yarısında Osmanlı Devleti'nde Tuzlaların İdaresi ve İşletilmesi" (Yüksek Lisans Tezi, Gazi Üniversitesi, 2016); Duygu Çakır, "Osmanlı Devleti'nin Son Döneminde Karadeniz'de Tuz Kaçakçılığı" (Yükssek Lisans Tezi, Ordu Üniversitesi, 2019); Abdurrezzak Çelik, "XIX. Yüzyılın İkinci Yarısında Siirt Sancağının İdari ve Sosyoekonomik Durumu" (Yüksek Lisans Tezi, Siirt Üniversitesi, 2019).

4 Haydar Kazgan, "Düyun-1 Umumiye", Tanzimat'tan Cumburiyet'e Türkiye Ansiklopedisi (İstanbul: İletişim Yayınları, 1985); Filiz Diğıroğlu, Memalik-i Osmaniye Duhanlar Müstereküll'-Menfaa Reji Şirketi (İstanbul: Osmanlı Bankaksı Arşiv ve Araştırma Merkezi, 2007); Murat Birdal, The Political Economy of Ottoman Public Debt: Insolvency and European Financial Control in the Late Nineteenth Century (Londra ve New York: Tauris Academic Studies, 2010).

5 Donald Quataert, Osmanl Devleti'nde Avrupa Iketisadi Yayllm ve Direniş (1881-1908) (Ankara: Yurt Yayınlar1, 1987).

6 Samuel Adrian M. Adshead, Salt and Civilization (New York: St. Martin's Press, 1992), 259, 270.

7 Birdal, The Political Economy, 22. 
ve hizmetleri bol ve ucuz bulundurması ilkesiyle taban tabana zit olarak bir metay1 hazine gelirlerini artırmanın bir aleti olarak görmesini paradoks olarak nitelendirmektedir. Osmanlı Devleti'nin neden böyle bir düzenleme yaptı̆̆ını anlamak için bunun ardında fiskalist saiklerin olup olduğunu sormakta fakat bunun için de gerek tuzla gelirlerinin gerekse tuz fiyatlarının zaman içinde pek de yükselmemesine işaret ederek fiskalist kayg1lar da olsa yine de tuz tekelinin asıl amacının iaşecilik olduğunu iddia etmektedir. ${ }^{8}$ Osmanlı ekonomisinin 19. yüzyılda ne kadar bu saikler doğrultusunda işlediği sorusu bir kenara bırakıldığında, Kwass ise büyük kamu borçlarını ödeyebilmek için Avrupa'daki -özellikle Britanya'daki tüketicileri derinden sarsan- vergilerin (gümrük vergileri ve bira, yerli içkiler ve tuz üzerindeki dolaylı vergiler) azami sınırlara geldiğini göstermektedir. Dahası, bu dolaylı vergilendirmenin sadece İngiliz ticari büyümesinin bir yansıması olmadı̆̆ını aksine bunun "tüketimi vergilendirilir hâle getirmenin" bir parçası olarak "yeni tür dolaylı vergiler yaratarak ve hâlihazırdakilerin oranını artırarak daha yüksek gelir elde etmek için kasıtlı bir politikanın sonucu" olarak değerlendirmektedir. ${ }^{9}$ Osmanlı ekonomisinde bu şekilde kurulan tekeller üzerinden dolaylı vergileri artırma girişimini, her ne kadar başarısı ayrı bir tartışma konusu olsa da, gelir ve servetin doğrudan vergilendirilmesine paralel bir gelişme olarak görmek gerekir. ${ }^{10}$

Alınan dış borçlara teminat olması haricinde, tuz tekeli şüphesiz Osmanlı maliyesinin 19. yüzyılda gelirlerini artırmak için denediği modern yöntemlerden biriydi. Bu bağlamda, Osmanlı hükümeti tuz gibi çok temel bir maddeyi bir dolaylı vergi unsuru yapmış ve her ne kadar başarısına dair güvenilir kayıtları olmasa da yeni bir gelir kaynağı elde etmişti. Tüketimin vergilendirilir hâle getirmesiyle birlikte tuz tekeli başka modern meselelere de yol açmıştı. Modern anlamda kaçakçılığın ortaya çıkmasında önemli bir kurum olan tuz tekeli Siirt özelinde ciddi bir tepkiye yol açış, Kürt mirleri, aşiret ağaları ve tuzla işçileri açısından yeni siyasi ve iktisadi dinamikler ortaya çıkarmıştı. Tuzun dolaylı vergi olarak tahsilatı yapılacak bir kaleme dönmesi sonrasında ortaya çıkan kaçakçılık, karşısında artan bir Osmanlı Devleti şiddetini görmüştü. Kaçakçılıkla mücadelenin gölgelediği yoksulluk ise tüm bu karmaşık yapının bir parçası olarak daha görünür hâle gelmişti. Bu çalışma, mali açıdan modern bir kurum olan Osmanlı tuz tekelinin, Siirt'te kaçakçıllk, şiddet ve yoksulluk sarmalı içinde 19. yüzyılın ikinci yarısından itibaren gelişen sosyoekonomik yapının asli unsurlarından biri olduğunu iddia etmektedir.

8 Mehmet Genç, "Osmanlı Mali Sisteminde Tuz ve Tuzlaların Mahiyeti", Osmanl Devleti'nde Nebirler ve Göller, ed. Şakir Batmaz ve Özen Tok (Kayseri: Not Yayınları, 2015), 201-04.

9 Michael Kwass, "Court capitalism, illicit markets, and political legitimacy in eighteenth-century France: The salt and tobacco monopolies", Questioning Credible Commitment: Perspectives on the Rise of Financial Capitalism, ed. Adrian Leonard, D'Maris Coffman ve Larry Neal (Cambridge: Cambridge University Press, 2013), 230.

10 Nadir Özbek, Imparatorluğun Bedeli: Osmanlida Vergi, Siyaset ve Toplumsal Adalet (1839-1908) (İstanbul: Boğaziçi Üniversitesi Yayınevi, 2015), 17-38. 


\section{Uğur Bayraktar}

\section{Osmanlı Tuzlaları ve Tekel}

Tuz idareleri dünyanın her yanında genel olarak vergilendirme, bürokrasi ve uzmanlaşmadan müteşekkildi. Bu üç husustan sonuncusu ise tuzu diğger metalardan farklı olarak ele alma imkânını barındırmaktaydı. ${ }^{11}$ Özellikle erken modern dönemde Osmanlı tuz idaresi bu hususlar göz önünde bulundurulduğunda, tuz tekelini andırmaktaydı. Bu dönemde mevzuat olarak maden hukuku içinde ele alınmasının da katkısıyla madenler üzerindeki devlet mülkiyeti tuz için de geçerliydi. ${ }^{12}$ Bir devlet malı olarak ele alınan, devletin ciddi ve önemli bir gelir kaynağını teşkil eden, üretiminin aşamalarını denetlediği ve fiyatını belirleyerek toptan veya birkaç kişiye ihale ederek bedelini belirlediği tuz bu hâliyle tekelbenzeri görünümündeydi Fakat bu tür uygulamalar yer yer ve zaman zaman gerçekleşmiş ve bu zincirin özellikle nakliye ve ticareti aşamalarının finansmanı kısmında gerekli sermaye özel kişilerce sağlanmıştı. ${ }^{13}$

İktisadi bir pratik ve kurum olarak tekel niteliklerinden yoksun olan bu yap1, tuzun vergilendirilmesi açısından Osmanlı toprak tasarrufu uygulamalarına benzerlik arz etmekteydi. Zira topraktaki terminolojiyi takip eden şekilde, Osmanlı tuzlaları; mültezimlerce işletilenler, devlet eliyle işletilenler, özel kişilerce işletilenler ve tekke, zaviye ve aşiret beylerine tahsis edilmiş olanlar olmak üzere dört ayrı sinıfa ayrılmaktaydı. ${ }^{14}$ Özellikle büyük üretim yapılan tuzlalar devlet malı sayılırken, kişisel girişim ve yatırımlarla ortaya çıkarılan özel mülkiyetli tuzlalar da söz konusuydu. Toprakta özel mülkiyetin yolunu açan "temlik" suretiyle, sultanlar tuzlaların da özel şahıslara devrini gerçekleştirmiş, temlik haricinde tekke ve zaviye mensupları tarafindan "ihya ve âbâdan" edilen çorak arazilerde faaliyete geçirilen tuzlalar bu müteşebbislere terk edilmişti. ${ }^{15} \mathrm{Bu}$ özel mülkiyetli tuzlalar hâricinde ise, Osmanlı toprak vergilendirmesindeki yaşanan değişimin benzerinin tuzla gelirlerinin yönetiminde yaşandığ1 söylenebilir. 18. yüzyıldaki Erzurum tuzlalarının gösterdiği üzere, birçok tuzla topraktakinden farksız olacak şekilde has, ocaklık, iltizam, emanet ve malikane olmak üzere çeşitli idare ve vergilendirme süreçlerinden geçmişti. ${ }^{16}$

19. yüzyıla gelindiğinde hız kazanan mali merkezileşme kapsamında, tuz gelirlerinin idaresi de muhassıllık yönetimine benzeşecek şekilde Osmanlı

11 Adshead, Salt and Civilization, 172.

12 Osmanlı maden mevzuatı için fikir vermesi açısından bkz. Ahmed Refik Altınay, Osmanl Devrinde Türkiye Madenleri, 967-1200 (İstanbul: Devlet Matbaası, 1931); Neşet Çağatay, "Osmanlı İmparatorluğunda Maden İşletme Hukuku", AÜ DTCF Dergisi 2, no. 1 (1943)., s. 107-16.

13 Müfit İlter, Türkiye'de Tuz Endüstrisi ve Tuz Ticareti, İkinci Kitap (Ankara: Tekel Genel Müdürlüğü, 1980), 7; Güçer, "XV-XVII. Asırlarda Osmanlı", 108; Genç, "Osmanlı Mali Sisteminde", 203.

14 Güçer, "XV-XVII. Asırlarda Osmanlı", 9-10; İlter, Türkiye'de Tuz Endüstrisi, İkinci Kitap, 9-10.

15 Savaş, "Osmanlı Döneminde Sivas'ta Tuz", 230-33.

16 Erim, "18. Yüzyılda Erzurum Tuzları", 224-25. 
defterlerinde kayıtlı olan tuzlalar Maliye hazinesince zapt edilmiş ve muhassıllarca tayin k1lınan memurlarca emaneten idare edilmişti. Muhasıllıktan iltizama geri dönülmesiyle birlikte tuzla gelirlerinin tahsilatında yine benzer bir dönüşüm yaşanmış ve tuzlalar da Osmanlı maliyesi tarafından birer ikişer sene olmak üzere mültezimlere maktuan ihale edilmeye başlanmıştı. Tuzların yatırım gerektirmesinden ötürü ve bu kısa vadede tuzlalara beklenen sermaye yatırımının gerçekleşmeyeceğinden endişelenen Osmanlı maliyesi, iltizam süresini uzatarak dört ila beş senelik olacak şekilde müzayede usulüne geçmişti. ${ }^{17}$

1838 Baltalimanı Ticaret Antlaşması sonrasında Osmanlı pazarlarının yabancı mallara açılması sonrasında, üretilen veya ithal edilen her tuzun, üretildiği yer veya giriş yaptığ1 gümrük itibariyle hangi coğrafi bölge dahilinde satılacağını belirleyen, yüzyıllar içinde pek de değişmemiş olan “örü” nizamı; ithal tuzun Osmanlı coğrafyasındaki satışını zorlaştırmaktaydı. ${ }^{18}$ İngilizlerin bu örü nizamını "yed-i vahid" uygulamasının devamı olarak görerek bunun serbest ticarete ve mezkur antlaşmaya aykırı olduğunu dile getirirken, Hariciye Nezareti ise yed-i vahid usulünü İngiliz Sefaretine açıklamakta ve tuzlaların mevzuatının bununla hiçbir şekilde kıyaslanamayacağını belirtmekte ve tuzlaların 'Devlet-i 'Aliye'nin kendi has malı" olduğunu açıklamakta devletin de "ol veçhile mülk-i mahsusunda çıkan tuzları bazı şerait ile ilzam ve ihale etmekte" olduğunu eklemekteydi. ${ }^{19}$ Her ne kadar Osmanlı yetkilileri tuzun bir "devlet malı" olduğu konusunda İngilizleri hoşnutsuz da olsa ikna edebildiyse de ithal tuzların örü nizamı dâhilinde kısıtlı bölgelerde satışının ilerideki olası sonuçlarını göz önünde bulundurmaktaydı.

Kırım Savaşı'nın Osmanlı maliyesinde yarattığ1 tahribat karşısında, tuzla gelirlerinin nasıl tahsil edileceği üzerine Osmanlı hükümetinde tartışmalar başlamıştı. ${ }^{20} \mathrm{Bu}$ tartışmalar, mali merkezileşme girişimleriyle birlikte tuzlaların birden çok mültezime ihale edilmesi yerine tek bir elden idare edilmesini de kapsamaktayd1. 1856'da Meclis-i Vala'da gerçekleşen bu tür tartışmalar sırasında İzmirli Cemaleddin Efendi Osmanlı topraklarındaki mevcut tuzlaların idaresi için bir kumpanya teşkilini, örü nizamının lağvını ve bu tuzlaların cari bedellerine senelik üç bin keseden on seneliğine otuz bin kese zam önerisiyle kendisine ihalesini teklif etmekteydi. ${ }^{21} \mathrm{Bu}$ teklifi takip eden diğer teklifler sonrasinda Osmanlı topraklarındaki tüm tuzlalar 1857 yılında açık artırmaya çıkarılmış ve Galata

17 İlter, Türkiye'de Tuz Endüstrisi, İkinci Kitap, 320.

18 Örü tanımı için bkz. Güçer, "XV-XVII. Asırlarda Osmanlı", 119.

19 BOA. İ.HR 102/4986, 21 Zilhicce 1269 (25 Eylül 1853).

20 Murat Hulkiender, Bir Galata Bankerinin Portresi George Zarifi 1806-1884 (İstanubul: Osmanl1 Bankası Arşiv ve Araştırma Merkezi, 2003), 46.

21 BOA. A.MKT.NZD 178/38, 29 Cemaziyelahir 1272 (7 Mart 1856). 
bankerlerinden Yorgo Zarifi'ye 202.500 keseye devredilmişti. ${ }^{22}$

Fakat çok geçmeden Osmanlı hükümetinin tuzlaları kumpanyaya devirdeki amacından uzaklaşmışıt. Zira, kumpanya tuzlaları kendi işletmek yerine, Tanzimat'in başından beri devam eden şekliyle yine ikinci ve üçüncü mültezimlere devretmiş ve bu da hâliyle tuz gelirleri idaresinde aranan dolaysız yönetime sekte vurmuştu. 23 "İkinci mültezim" meselesi olarak çetrefilleşecek bu ihtilaf karşısında Osmanlı devleti Zarifi'nin önderliğindeki kumpanya ile yapılan anlaşmayı feshetmek istemişti. Zarifi ve diğer bankerler, mutabık kalınan koşullar arasında tuz üretimi ve gelirlerinin tahsilinin aracısız olması gerektiğine yönelik bir hüküm olmamasını öne sürerek bu fesih girişiminin hukuka aykırılığını ileri sürmüş ve zararlarının devletçe tazminatını talep etmişti. ${ }^{24}$ Oldukça karmaşık bir hâl alan bu ihtilaf müzakerelerinde, meselenin çözümü adına Zarifi meclise iki teklif sunmuştu. Bunlardan biri yabanci tüccarların faaliyetlerinin engellenmesiyle iltizamın devam etmesi, ikincisi ise Zarifi'nin tuzlalardan elde ettiği 50 bin keselik kârı hazineye terk ederek o vakte kadar yaptığ harcamaların karşılı̆̆1 olan 20 bin kesenin kendisine ödenmesiyle ihalenin feshiydi. ${ }^{25}$

Süregelen müzakereler sonucunda bir çözüm bulunamayınca, Meclis-i Vala, Maliye Nezaretiyle fikir alışverişi sonrasında 1860'ta tüm tuzlaların “toptan fesh-i ihalesiyle parça parça müzayedeye konularak taliplerine" verilmesine karar vermişti. ${ }^{26}$ Fakat bu tekrar ihale kararı da ardından çok zaman geçmeden bir kenara bırakılmıştı. Osmanlı hükümeti, ikinci mültezimler ve Zarifi'nin önderliğindeki kumpanya ile hâlâ tazminat meseleleri masadayken, tüm tuzlaların Rumi "[12]77 [1861] senesi Martından itibaren emaneten idaresi"ne karar vermişti. ${ }^{27}$ Osmanlı maliyesinin içinde bulunduğu sıkışıklığ1 da yansıtacak veçhile, gerekli alet ve edevatın temini ve tuzlaların tamiri mal sandıklarından karşılanacaktı. Tuz gelirinin tahsilatında ise iki seçenek söz konusuydu. Birinci seçenek, hazine için elverişli durumlar söz konusu olduğunda tuzlaların maktuan ihale olunması ve hasılat ve masraflar sonrasında mültezimlere devrolunmasıken ikinci seçenek de emanette kalmasıydı ki bu durumda tüm gelirler "hiçbir mahalle sarf olunmayıp" tamamıla Maliye Nezaretinin belirlediği yerlere havale edilecekti. ${ }^{28}$

22 İlter, Türkiye'de Tuz Endüstrisi, İkinci Kitap, 326-28. Banker Zarifi için bkz. Hulkiender, Bir Galata Bankerinin Portresi; Haydar Kazgan, Galata Bankerleri, 2. cilt (Ankara: Orion Yayınevi, 2006), 73-76.

23 İlter, Türkiye'de Tuz Endüstrisi, İkinci Kitap, 12.

24 İlter, Türkiye'de Tuz Endüstrisi, İkinci Kitap, 12-13.

25 Çakır, "Osmanlı Devleti'nin Son", 17.

26 BOA. İ.MVL 438/19435, 18 Rabiulahir 1277 (3 Kasım 1860).

27 BOA. A.MKT.UM 454/83, 2 Şaban 1277 (13 Şubat 1861). Ayrıca bkz. BOA. A.MKT.NZD 342/37, 1 Şaban 1277 (12 Şubat 1861).

28 BOA. A.MKT.UM 454/83, 2 Şaban 1277 (13 Şubat 1861). 
Birkaç ay sonra ise bu yöntem sonrasında "ekserisinin yedd-i emanette bulunması" zaten bir yandan devam etmekte olan "inhisar" tartışmalarına katkıda bulunmaktaydı. ${ }^{29} \mathrm{Bu}$ tartışmalar devam ederken Osmanlı mevzuatında da değişimler söz konusuydu. Tuz, 1861 Maden Nizamnamesi diğer değerli cevherlerden ayrilmış, 1861'de önce Fransa ile sonra diğer birçok Avrupa ülkesiyle akdedilen Kanlica Ticaret Anlaşmalarıyla tuz ithalatı yasaklanmış ve Osmanlı hükümeti tuz tekeli için hazırlıklar yapmıştı. ${ }^{30}$ Anlaşmalar imzalanmadan tekele geçmenin yaratacağı diplomatik sorunlar, tuz üretimi mevsimini kaçırmanın tuz arzında ve fiyatında ortaya çıkaracağı meseleler, tekke ve zaviyelere tahsis edilmiş tuzlaların akıbeti ve yurtdışından hâlihazırda tuz ithal etmiş olan tüccarların tabi olacağı hükümler gibi çeşitli konuların tartışlması sonrasında Osmanlı hükümeti 1862 Martindan itibaren "memalik-i saireden gelen tuzun men'-i ithaliyle devlet-i aliyyenin memlehalarının taht-1 inzibata ve inhisara" alınmasına karar vermişti. ${ }^{31} \mathrm{Bu}$ karar sonrasinda, vakıf tuzlalar için 663.009 kuruş 22 para, özel mülkiyet tasarrufundaki tuzlaların sahiplerine de 202.822 kuruşluk tazminat ödenmesi kabul edilmiş; ilk taksitin nakit, ikincisinin de devlet tahvili olarak iki yılda ödenmesi planlanmışt1. 32

Mart 1861'de tuzlaların "emaneten" işletilmesi süreciyle başlayan tuz tekeline Avrupa'da Aynaroz, Selanik, Gümülcine, Ohri, Berat, İslimye (bugün Sliven), Golos (bugün Volos), Yanya sancakları ve Rodos, Kıbrıs, İstanköy (bugün Kos) ve Girit adaları ile Anadol"da Sivas'taki başta Hamo ve Artvin tuzlaları başta olmak üzere, Siirt sancağındaki Dergül, Eruh, Pervari ve Şirvan'daki tuzlalar başı çekmekteydi. Bunların yanı sıra Diyarbekir, Biga, Bozok, Manisa, Ankara, İzmir, Kangırı, Niğde, Van, Erzurum, Burdur, Teke, Karahisar-1 Sahib, Bayezid, Kars, Muş, Çıldır, Dersim Adana ve Erzurum sancaklarındaki tuzlaların yanı sıra Beyrut, Gazze, Ramallah civarındaki Levant tuzlalarıla birlikte Halep, Bingazi, Şehrizor ve Basra gibi Osmanlı merkezlerine görece uzak yerlerde bulunan tuzlalar da tekele dahil edilmişti. ${ }^{33} \mathrm{Bu}$ bağlamda, gelirinin fazla olacağ1 tahmin edilen Kıbrıs ve Beyrut tuzlaları gibi yerlere İstanbul'dan "mutemet ve müstakim” eminler tayin edilirken, gelirlerinin memur maaşlarını karşılamayacağı öngörülen tuzlalar da yerel

29 BOA. İ.MMS 24/1028, 24 Cemaziyelevvel 1278 (27 Kasim 1861).

30 Fahrettin Tızlak, "Osmanlı Maden İşletmeciliğinden Kanunnâmeden Nizamnâmeye Geçiş ve 1861 Tarihli Maden Nizamnâmesi", Türk Dünyası Araştırmaları, no. 98 (1995): 79-81; Mübahat Kütükoğlu, "Tanzimat Devri Osmanl1-İngiliz Gümrük Târifeleri", Tarih Enstitüsü Dergisi, no. 4-5 (1973-74): 346; Stefanos Yerasimos, Azgelismişlik Sürecinde Türkiye, 2. Cilt Tanzimattan I. Dünya Savaşına (İstanbul: Gözlem Yayınları, 1975), 767-76. Eylül 1861 itibariyle, Fransa, İtalya ve İngiltere ile bu anlaşmalar imzalanmış, Rusya ve Avusturya ve Belçika ve Yunanistan ise henüz bu yeni koşulları tasdik etmemişti. BOA. İ.MMS. 24/1028, 24 Cemaziyelevvel 1278 (27 Kasım 1861).

31 BOA. İ.MMS 24/1028, 24 Cemaziyelevvel 1278 (27 Kasim 1861).

32 İler, Türkiye'de Tuz Endüstrisi, İkinci Kitap, 13.

33 Toplamda 11'i Avrupa'da olmak üzere 41 tuzla söz konusuydu. BOA. A.MKT.UM 454/83, 2 Şaban 1277 (13 Şubat 1861). 
meclislerce idare edilecekti. ${ }^{34} \mathrm{Bu}$ idari düzenekte tuz müdürleri -s1klıkla Düyun-1 Umumiye ile ilişkilendirilmiş olan- kolcu başta olmak üzere, katip ve kantarc1 gibi memurları seçmekle yükümlüydü. ${ }^{35} \mathrm{Bu}$ idari yapılanmaya, tuz tekelinin kuruluşundan birkaç sene sonra Osmanlı taşrasında tuz satışına dair sıkıntılar çıkması sonrası tuz satışı yapan mağazalar da eklenecekti. Bunun ardında, Rüsumat Emaneti’nin raporlarına göre, tüccarların tuzlalardan aldığı tuzu nakliye maliyetleri ve kârlarıyla birlikte sattıkları şehir ve kasaba esnafinın kendi arasındaki ittifakla ufak meblağlar için tuzlalara gitmeyenlere fahiş fiyatlarla tuz satması yatmaktaydı. ${ }^{36}$

1862'de yayınlanan Tuz Nizamnamesi'nin koşullarını belirlediği tekel ile tüm kaya ve deniz tuzu çıkarılan yerler Rüsumat Emaneti'ne devredilmişti. ${ }^{37}$ Tuzun üretim ve satışını devlete bırakan bu uygulamaya göre, tezkeresiz alınıp satılan tuzların yakalanması "sirkat" addedilerek 18. bend uyarınca bu tuz müsadere edilecek ve tuzun iki katı değerindeki “ceza-y1 nakdi” bu kişiden tahsil edilecekti. ${ }^{38}$ 1861'de yapılan tartışmalar bağlamından farklı olarak nizamnameye göre tuz üretimi ve ticaretinin denetimi için öncelikle tuzla idareleri yerine göre çeşitli bölgelere taksim edilecek ve her merkezin başında müdür, başkatip, sandık eminleri gibi memurlar bulunacaktı. Önce bu memurların maaşlarının üçte birlik kısmının azaltılarak bu kesintinin tekelin gelirlerinin yüzde 2'siyle karşılanması tartışıldıysa da tuz üretiminin büyük ölçüde yazın gerçekleşmesi ve memurların yaz sonuna kadar tuzla gelirlerini -ve dolayısıyla tam maaşlarını- elde edemeyeceği düşünülerek bu fikir bir sonraki seneye birakılmıştı. ${ }^{39}$

Osmanlı Devleti'nin 1856'da başlayan diş borçlarıyla hızlanan mali buhranının gelişiminde en temel dayanaklardan biri olan tuz tekeli, bu saikle temel olarak yeni diş borçlara teminat sağlamak için kurulmuştu. ${ }^{40} 19$. yüzyılın ortasından itibaren Avrupa piyasalarıyla olan etkileşim sonrasında Osmanlı hükümetinin kredibilitesini geliştirmek için geliştirilmiş olan bütçe reformunun bir devamı olarak görülebilecek bu kurum, tütün ve posta pulu (evrak-1 sahiha) gelirleriyle birlikte 1862'de Osmanlı Bankası aracılığılya Avrupa'dan alınan borca da teminat olarak gösterilmişti. ${ }^{41}$

34 BOA. İ.MMS 24/1028, 24 Cemaziyelevvel 1278 (27 Kasim 1861).

35 BOA. A.MKT.NZD 404/97, 3 Ramazan 1278 (4 Mart 1862).

36 BOA. A.MKT.MHM 387-A/83, 18 Rabiulevvel 1284 (20 Temmuz 1867).

37 “Tuz Nizamnamesi ve Zeyli", Düstur, Tertip 1, Cilt 2 (İstanbul 1279 [1863]), 683-706. Ayrica bkz. Kasım, "Tuz Nizamnamesi", 106-23.

38 Demirel, "Osmanlı Devleti'nde Tuz", 153.

39 BOA. İ.DH 488/33013, 25 Şevval 1278 (25 Nisan 1862); BOA. A.MKT.NZD 414/4, 29 Şevval 1278 (29 Nisan 1862).

40 Donald C. Blaisdell, European Financial Control in the Ottoman Empire: A Study of the Establishment, Activities, and Significance of the Administration of the Ottoman Public Debt (New York: Columbia University Press, 1929), 109; Adshead, Salt and Civilization, 263.

41 Birdal, The Political Economy, 30; Dığıroğlu, Memalik-i Osmaniye Duhanlar, 28. 
Meclis-i Mahsus bütçeye ve olası diş borç alımına katkı olarak oldukça iyimser denebilecek şekilde tuz gelirlerini şu şekilde hesaplamıştı. Osmanlı İmparatorluğu nüfusunu - sayıma tabi tutulmamış bölgeleri de tahmin ederek - 30 milyon kişi olarak hesap eden meclis azaları her kişinin zaruri olarak yılda 6 okka tuz tüketeceğini tahmin ediyordu. Bu hesapla ortaya çıkan 180 milyon okka insan tüketimine, sanayi ve hayvancilıkta kullanılacak 120 milyon okka tuzu katıyordu. ${ }^{42}$ Buna tekelin tuzlada satılacak olan her bir okka tuz için 10 para, sahile indirilecek ve başka yere nakledilecek tuz için 15 para ve iç bölgelerde satılacak tuz için 25 para şeklinde belirlediği tarifenin en düşük kademesinden hesaplama yapıldığında, 75 milyon kuruşluk bir gelir ortaya çıkıyordu. Her okkadaki üretim maliyeti toplamı olan 10 milyon kuruş da düşüldüğünde Osmanlı tuz tekelinin y1llık geliri 65 milyon kuruş olarak tahmin edilmekteydi. Elbette bu hesaplama yöntemi, Avrupa sermayedarlarının Osmanlı maliyesinin ortaya çıkardığı kayıtlara ilişkin çekincelerini doğrular nitelikteydi.43

Tüm imparatorluk dâhilinde bu şekilde belirlenmiş tuz fiyatları, tekel öncesindeki kumpanyanın belirlediği fiyatlarına göre ciddi bir zammı da içermekteydi. Bu zam, Zarifi kumpanyasına devredilmesi sırasında karara bağlandığı şekilde tuzlalarda satılan tuzun okkasının 6 para, tuzlaya civar olan yerlerdekilerin 10 para ve daha uzak yerlerde, orasının rayiç bedeliyle satılacak fiyatlar düşünüldüğünde yaklaşık yüzde 16 ilâ yüzde 50'yi buluyordu. Fakat müzakerelerde ilkin belirlenen fiyatlar da kalıcı olmamış, yapılan ilâve bir zamla Hazine bütçesindeki "bir müddetten beri zuhur eylemiş olan açığa ehem ve elzem görünen karşılık" olmak üzere tuzlada satılacak bir okka tuz 15 para, sahile indirilecek ve başka yere nakledilecek tuz 20 para ve iç bölgelerde satılacak tuz 30 para olarak belirlenmişti. ${ }^{44}$

\section{Siirt'te Tuz Tekeli}

Erken modern dönemdeki tuzlalara dair çalışmalara temel teşkil eden kanunnamelerde kendine yer bulamayan Sïrt tuzlaları, 19. yüzyıla geldiğimizde Diyarbekir'e bağlı on tuzlanın sekizini teşkil etmekteydi. ${ }^{45} \mathrm{Bu}$ tuzlalar, Zırki, Melefan, Sulha, Sason, Küfre, Sadah, Kilis ve Serhel tuzlalariydı. Bu tuzlaların üretim ve istihdam kapasitesine dair 19. yüzyıl verileri oldukça k1sıtlı olsa da

42 BOA. İ.MMS 24/1028, 24 Cemaziyelevvel 1278 (27 Kasım 1861).

43 Yerasimos, 1874-75 mali ylı bütçesinde tuz tekelinin 825 bin Osmanlı lirası olarak belirlenen tahminine ancak 1900 yllında ulaşıldığını belirtmektedir. Yerasimos, Ažgelişmislike Sürecinde Türkijye, 2. cilt, 979. Osmanlı tuz tekelinin 1879-1914 arasındaki gelirlerine dair en güncel rakamlar için bkz, Birdal, The Political Economy, 111.

44 BOA. İ.MMS 24/1028, 24 Cemaziyelevvel 1278 (27 Kasım 1861).

45 Cihan, "Osmanlı Kanunnamelerinde Tuz", 2. Diyarbekir vilâyetine bağlı olan diğer iki tuzla, Lice ve Bulanık tuzlalarıydı. Salname-i Vilayet-i Diyarbekir, defa 6 (1288 [1871]), s. 142-48. Ayrica bkz. Vital Cuinet, La Turquie d'Asie, géographie administrative : statistique, descriptive et raisonnée de chaque province de l'Asie Mineure, 2. cilt (Paris: E. Leroux, 1891), 539-40. 
Düyun-1 Umumiye İdaresi ve Cumhuriyet dönemindeki araştırmalar bu tuzlalara dair bir fikir vermekte. Bu bilgiler 1şığında - Tablo 1.de görülebileceği üzere - 1890 civarında Siirt'te Düyun-1 Umumiye tarafindan işletilen altı tuzlanın yıllık üretiminin yaklaşık yedi ton olduğu ve bu üretimin Bitlis vilayetinin güneyi ve vilayetin Van, Musul, Diyarbekir, Mamuretülaziz vilayetlerine sınır olan kazalarının tüketimine yeterli olduğu bilinmekte. ${ }^{46} 1890$ yil itibariyle Cuinet'nin - kadim usullerle yalnızca Kürtlerin çalışmış olduğunu belirttiği tuzlalarda çalışan kişilerin sayısına dair bir fikir elde etmek oldukça güç olsa da İlter'in 1980 gibi geç bir tarihte sunduğu veriler tuzlaların yarattığ istihdama 1 şık tutabilir. ${ }^{47}$ Buna göre, çoğu tuzlanın bu dönemde idari kadrosu bir memur ve iki bekçiden, çalışan kadrosu ise bir-iki daimi işçiye eşlik eden 10 ila 25 arasında değişen mevsimlik işçilerden oluşmaktaydı. ${ }^{48}$

$\mathrm{Bu}$ tuzlalardan bu çalışmanın odaklandığı Melefan ve Zırki tuzlaları, 1980 kadar geç bir tarihe kadar hâlen işletilmekteydi. ${ }^{49}$ Salnamede belirtildiğine göre, Melefan tuzlası, Garzan kazasının merkezi Zok köyüne üç saat mesafede olup bölgedeki diğer birçok tuzla gibi taşlık ve dağlık bir bölgedeydi. Melefan köyünün kendisi 200 haneye yakın olmakla birlikte Haziran başından Ekim sonuna kadar 20 arşın derinliğinde 40 kuyudan çekilen tuzlu suyu 383 tabada tuzlada çalışan köylü işçiler buharlaştırarak üretmekteydi. İşçilerin ücreti üretilen tuz başına okkada 4,5 para olup tuzlanın üretimi 1 milyon okka iken talep halinde bir bu kadar daha tuz üretebileceği belirtilmekteydi. Düyun-1 Umumiye geçmiş tuzlalar için 1890 yllı itibarıyla Cuinet fiyatların ton başına 30 ila 45 kuruş arasında değiştiğini belirtmekte ve Melefan tuzlalarının "eski sahiplerine" ödenen küçük meblağlardaki ücretlerle ton başına 56,5 kuruşa çıktığını eklemekteydi. ${ }^{50}$ Zırki tuzlası yine taşlık ve dağlık bir coğrafyada 15 haneli Deklan karyesinde olup, Siirt'e bir saat mesafe uzaklıktaydı. 28 kuyusu ve 3 tabası ve 1 havuzuyla birlikte işçileri de Melefan tuzlasındaki gibi ücret almakta ve bu tuzla 500 bin okka tuz üretirken yine bir o kadar daha kapasiteye sahipti. ${ }^{51}$ Her ne kadar 1980 gibi bir tarih, 19. yüzylldaki istihdam verilerini yansıtmaktan uzak olsa da bu dönemde Melefan tuzlasında iki memur, dört bekçi, üç daimi ve 25 mevsimlik işçi; Zırki tuzlasında ise bir memur, iki bekçi, iki daimi ve 11 mevsimlik işçi Mayıstan Kasıma kadar sırasıyla ortalama 36 ve 56 gün boyunca

\footnotetext{
46 Cuinet, La Turquie d'Asie, 2, 539.

47 Cuinet, La Turquie d'Asie, 2, 540.

48 Sadah tuzlasında sadece bir memur ve bir daimi işçi varken, Sulha tuzlasında bir memur, üç bekçi, iki daimi ve 24 mevsimlik işçi bulunmnaktaydı. İlter, Türkiye'de Tu乏 Endüstrisi, İkinci Kitap, 48-64.

49 İlter, Türkiye'de Tuz Endüstrisi, İkinci Kitap, 47-48. 1971'de Siirt tuzlalarının Türkiye'deki diğer tuzlalarla karşılaştırmalı bir değerlendirmesi için bkz. "Üretim Bölgeleri Yönünden Karşılaştırma ve Değerlendirme", Bilimsel Madencilik. Dergisi (1974): 51-52.

50 Cuinet, La Turquie d'Asie, 2, 540, not 1.

51 Salname-i Vilayet-i Diyarbekir, defa 6 (1288 [1871]), s. 142-45.
} 
tuz çıkarma işinde çalışmaktayd1. ${ }^{52}$

Tablo 1. Siirt Tuzlalarında Üretilen ve Tüketilen Tuz Miktar1 ${ }^{53}$

\begin{tabular}{|c|c|c|c|c|c|}
\hline & 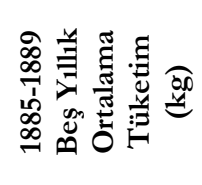 & 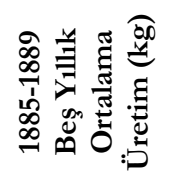 & 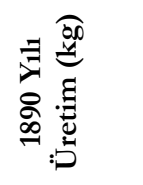 & 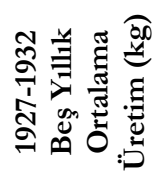 & 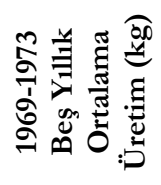 \\
\hline Melefan* & $2,400,000$ & $2,500,000$ & $3,026,789$ & 899,800 & 801,000 \\
\hline Sulha & $1,100,000$ & $1,200,000$ & $1,300,176$ & 626,800 & 725,200 \\
\hline Zirki & 775,000 & 850,000 & 945,959 & 640,600 & 373,600 \\
\hline Küfre & 725,000 & 800,000 & 870,389 & 802,600 & 672,600 \\
\hline Sadah & 730,000 & 800,000 & 855,852 & 582,200 & $1,605,000$ \\
\hline Serhel & 250,000 & 250,000 & 233,935 & 394,000 & 609,800 \\
\hline
\end{tabular}

* Cumhuriyet döneminde, Melefan'a bağlı Çay Tuzlası da dâhil.

Tekelin kurulmasının ardından tuzlaların devlete devrinde ise Siirt'te birkaç y1l sürecek muhalefet de başlamıştı. 1862 yazında Melefan ve Norşin (günümüzde Batman'a bağlı Alıçlı köyü) karyelerindeki tuzlaların sahibi olma iddiasında olanlar tekel yönetimine muhalefetle tuz müdürünü tuzlalara yaklaştırmamaktaydı. Kürdistan valisine yazılan emirde bu hareketin gayrimeşru olduğunun altı çiziliyor ve bu kişilerin önce sözlü olarak "ikna edilmesi” bunu anlamadıkları taktirde tehdit ve tahvif edilmesi isteniyordu. ${ }^{54}$ Benzer bir durum, Şirvan'da bulunan Küfre tuzlasında da söz konusuydu. Erzurum tuzla müdürü tarafından gönderilen memuru kabul etmeyip geri gönderen halkın muhalefeti sonrasinda, tuzla "tavaif-i ekradın eyyad-1 tagallübünde" kalmıştı. Tuz mevsiminin de sona yaklaşmasılyla tuz geliri tahsil edilememesinden endişelenen Gümrük Emaneti gaile çıkarmaksızın olayın hallolmasını Kürdistan valisine iletmekteydi. ${ }^{55}$ Tuzlaların devlete devrine muhalefet ve tuz hırsızlığı şeklinde gerçekleşen bu ilk tepki elbette sadece Siirt'e özgü değildi. ${ }^{56}$

Bu muhalefetle doğrudan alâkasını kurmak zor olsa da Osmanlı tuz tekelinin de kurumsal gelişimi devam etmekteydi. 1863 Şubatında memur maaşlarında gidilecek tasarrufa yönelik başlayan tartışmalar sonrasında 35 tuz merkezi ve 33 tütün idaresi 1861'de kurulmuş Rüsumat Emanetiyle birleştirilerek 17 merkeze

52 İlter, Türkiye'de Tuz Endüstrisi, İkinci Kitap, 54, 63.

53 Cuinet, La Turquie d'Asie, 2, 540; İlter, Türkiye'de Tuz Endüstrisi, İkinci Kitap, 48-64.

54 BOA. A.MKT.MHM 239/71, 29 Safer 1279 (26 Ağustos 1862).

55 BOA. A.MKT.MHM 240/6, 16 Rabiulevvel 1279 (11 Eylül 1862).

56 Adana civarında Sırkıntı aşireti üyelerince benzer bir durum için bkz. BOA. A.MKT.MHM 245/2, 3 Cemaziyelevvel 1279 (27 Ekim 1862); BOA. A.MKT.MHM 248/40, 7 Cemaziyelahir 1279 (30 Kasim 1862). 
sahip Rüsumat Nezareti kurulmuştu. ${ }^{57}$ Bunda taşradaki gümrük, tuz ve tütün idaresinin küçük rütbeli memurlarla yapılmasının zorluğunun da altı çizilmekteydi. Çok sayıda küçük memur yerine daha üst rütbeli ama az sayıdaki memurla hem Osmanlı maliyesinde bir tasarruf hem de idarede etkinlik amaçlayan bu kararla, nezaretin çalışanlarının aylık maaş tutarı 27 bin kuruşa varmıştı. ${ }^{58}$

Siirt'teki Kürt mirleri ve aşiret ağalarının iç içe geçtiği girift düzen, 1863 yılında buradaki tuzlaların tekele devrinde büyük sorunlar yaratacağını ortaya koymaktayd1. Meclis-i Vala'da büyük memurların tercihi lehine tartışmalar söz konusuyken, Kürdistan valisi ise tütün ve rüsumat açısından en büyük kusuru büyük küçük ayırt etmeksizin tuzla tüm memurlara atfetmekteydi. ${ }^{59}$ Elbet valinin bahsettiği küçük memurlar, çoğunlukla yerel Kürt eşraf veyahut aşiret ağalarıydı. Tuzla müfettişi olarak Siirt'e gönderilen Vehbi Efendi'nin yaptığ1 araştırmaya göre, Siirt meclis azası Fettah Bey ve Garzan müdürü olan kardeşi Hamid Bey, bulundukları yerde kaldıkça Melefan tuzlasında işler asla yoluna girmeyecekti. Fettah Bey'in akrabalarından olan Bedirhan ve Abdal Beyler, bölgedeki Norşin tuzlasının devletin kontrolünden çıkmasında "müstakil bir sebepti." Elbette, Fettah Bey ve kardeşinin yerel yönetimdeki mevkilerinin yanında bir de özellikle Alikan ve Pencinarî aşiretleri üzerinde söz sahibi olup bunları seferber edebilme yetileri tuzlaların devlete devrinde ciddi bir sorun arz etmekteydi. ${ }^{60}$ Müfettişin araştırması yine Fettah Bey'in himayesinde olan Alikan aşiretinden Ömer Ağa'nın, Sulha tuzlasından bin yükten fazla tuzu gasp ettiğini ortaya koymaktaydı. ${ }^{61}$ Hazzo 114 (günümüzde Batman’a bağlı Kozluk ilçesi) tuzlasının da "elden” çıkması" yine Fettah Bey'in “adamı” sayılan Sason meclis azası Şeyh Süleyman'ın eseriydi. Müfettiş Vehbi Efendi’nin Siirt tuzlalarına yönelik tehdit olarak gördüğü ikinci bir grup da Siirt meclis azası Şir Bey ve oğlu Şirvan müdürü Osman Bey'di. Bu iki beyin Pervari meclis azaları olan Hacı ve Kasım Ağalar ile kurdukları şebeke, tuzların nakliyle görevlendirilmiş bir başka meclis azası olan Abdülselam Efendi'ye -rayicinden fazla at kiralayarak- zorluk çıkartarak tekelin Siirt'te yerleşmesindeki önemli engellerden birini oluşturmaktayd1.

1863'te tuz üretiminin gerçekleştiği yaz aylarında Siirt'teki tuzların devri bu girift ilişkiler ağı arasındaki mücadelelere bağlıydı. Osmanlı hükümeti tekelin tesisi

57 Stanford J. Shaw, History of the Ottoman Empire and Modern Turkey, 2. Cilt: Reform, Revolution, and Republic: The Rise of Modern Turkey, 1808-1975 (New York: Cambridge University Press, 1977), 103. Ayrica bkz. BOA. İ.MVL 481/21827, 14 Şaban 1279 (4 Şubat 1863).

58 BOA. İ.MVL 482/21839, 29 Şevval 1279 (19 Şubat 1863), BOA. İ.MVL 482/21854, 4 Ramazan 1279 (23 Şubat 1863).

59 BOA. A.MKT.MHM 263/22, 22 Zilkade 1279 (11 May1s 1863).

60 Alikan ve Pencinarî aşiretleri için bkz, İsmail Beşikçi, Doğu'da Değissim ve Yapısal Sorunlar (Göçebe Alikean Assireti) (Ankara: Yurt Kitap Yayın, 1992); Nezirê Cibo, Kürt Taribinde Garzan ve Pencinarîler (İstanbul: İsmail Beşikçi Vakfı Yayınları, 2016).

61 BOA. A.MKT.MHM 263/22, 22 Zilkade 1279 (11 Mayıs 1863). 
için bu aşiret bağları da olan yapının parçalanması kanaatindeydi. Bu bağlamda, tekelin geleceği için tehdit olarak belirtilen Fettah, Hamid, Şir ve Osman Beyler'in Sürt'ten alınarak eyalet merkezi olan Diyarbekir'e "celbi" elzem görülürken, hükümetin işi "gailesizce" halletme yönündeki beklentisi bölgedeki halkın "tuz imal etmemeleri” ihtimali gerçeğiyle birlikte yerini Sürt'e sevk olunacak bir tabur askerin çözeceği bir durum hâline getirmişti. ${ }^{62} \mathrm{Bu}$ sırada, Melefan tuzlası civarında, bölgedeki iki aşiretten Sloqî ve Etmanki arasında şiddetli bir çatışma çıkmıştı. 150 kişinin hayatını yitirdiği bu çatışma esnasında Diyarbekir tuzla memuru ise tuzla ambarlarının Kürtlerin saldırısından muhafazası için askeri yardım istemekteydi. ${ }^{63}$ Bunun üzerine Diyarbekir'den gönderilen Abdülkadir Bey, Siirt'te askeri bir müdahaleye girişmiş ve sonrasında tuzlaların korunmasını "muteber ekrad"a taahhüt ettirerek senet almış ve dönmüştü. ${ }^{64}$

Bölgedeki eşrafın aşiret güçlerini de seferber etmesiyle Siirt’teki tuzlaların tekele geçmesi kısa sürede bölgesel bir sorun hâlini almıştı. Belgelerden anlaşıldığı kadarıyla, Garzan'ın eski Kürt beylerinden olan ve Kasım 1854'te başlayıp Mart 1855’te sonlanan Yezdanşêr isyanı sonrasında Vidin'e sürülmüş olan Nuh Bey'in geri dönmesinin ardından Fettah Bey ile giriştiği tuzla mücadelesi, devletin de bu tuzlalarda hak iddia etmesi ile birlikte iyice karmaşık hâle gelmişti. ${ }^{65}$ Erzurum'dan gönderilen memuru Zırki tuzlasına kabul etmeyen halk karşısında, Muş kaymakamı Şevki Efendi ve müfettiş Vehbi Efendi başka bir memur atanması durumunda bunun da halk tarafından kabul edilmeyeceğinin farkındalığıyla Nuh Bey’i Kürt mirlerden olması ve bölge ahalisi nezdinde "hatırı geçen" biri olması sebebiyle kefilsiz olarak tuzlaya memur tayin etmişti. ${ }^{66} \mathrm{Bu}$ sayede Zırki tuzlası tekele dâhil olmuştuysa da çok geçmeden Nuh Bey’in Kasım Ağa ile birlikte tuzladan çok miktarda tuz çalınmasına sebebiyet vermesi Osmanlı yetkililerinin yerel eşraftan olan tuzla memurlarına yönelik rehavet eleştirilerinin karşılığını vermişti. ${ }^{67} 1863$ yazı biterken eyalet merkezine "celbi" gereken Fettah, Şir, Hamid ve Osman Beylerin hâlâ Diyarbekir'e gönderilmemiş olmasıyla Abdülkadir Efendi Ekim ayında dört bölük asker ve bir topla Siirt'e gitmişti. ${ }^{68}$ Sonuçları bilinmese de bu askeri operasyon, devletçe “celbi” lazım gelen Kürt beylerini Diyarbekir'e götürmeyi başaramamıştı.

62 BOA. A.MKT.MHM 271/46, 11 Safer 1280 (28 Temmuz 1863).

63 BOA. MVL 649/74, 24 Zilhicce 1279 (12 Haziran 1863).

64 BOA. MVL 659/81, 1 Cemaziyelevvel 1280 (14 Ekim 1863).

65 Yezdanşêr'in isyanı hakkında kısa bilgi için bkz. Metin Atmaca, "Origins of the "Kurdish Question"? The Revolt of Yezdanşêr (1854-1855)", The Routledge Handbook of the Crimean War, ed. Candan Badem (Londra: Routledge, 2022).

66 BOA. A.MKT.MHM 387-B/16, 19 Receb 1284 (16 Kasim 1867).

67 BOA. A.MKT.MHM 270/66, 4 Safer 1280 (21 Temmuz 1863).

68 BOA. MVL 659/81, 1 Cemaziyelevvel 1280 (14 Ekim 1863). 


\section{Uğur Bayraktar}

Tuz tekeli elbette sadece tuz gasp1 ve kaçakçıllğından ibaret değildi. Tuz tüccarından da taşıdıkları tuzun tezkeresinde yazandan fazla çıkması durumunda Tuz Nizamnamesinin kendilerini "hırsız" addetmesi huzursuzluk yaratmısstı. Nizamnameye eklenen zeyilde tezkerede yazan tuzun fazlası için yüzde üçe kadar mevcut tuzun değerinin bir katı, yüzde üçten fazlası için ise nizamnamede var olan iki katı tutarında nakit ceza belirlenmişti. ${ }^{69}$ Tüccara karşı yapılan bu "teshilat"a rağmen tuz tüketicilerini bekleyense zam idi. En son alınmış diş borcun başlayacak faiz ve anapara ödemesi için 1864 bütçe planlarında 260 bin keselik bir açık olması sebebiyle, tuzun eski fiyatı olan 20 paraya "halkın hissedeceği surette olmayan" 10 paralık zamma karar verilmişti. ${ }^{70}$ İstanbul'da imparatorluk fiyatında geçerli olacak tuzun fiyatına yapılacak zam tartışmaları söz konusuyken, tuz tekelinin Osmanlı tüketicileri üzerindeki etkisinin adi bir hırsılık ötesinde bir mesele olduğunu Melefan muhtarı Şêxo göstermişti. Yanında köy halkıyla bulunan Şêxo, tuzla müdüründen "ücret-i nakliye ve ihraciye olmak üzere" tuz üretimi için dörder buçuk para talep etmiş, bunun yanında tuzlanın sandığından 20 bine kuruş yakın para gasp etmişti. Devlete ait tuzlalara karşı bu tür hareketlere karşın, Kürdistan valisine Melefan tuzlasının yirmi ilâ otuz zaptiye ile korunması salık veriliyor ve "sadece yazılı ve sözlü uyarı ile iktifa olunmayarak fiiliyatı görülecek" etkin sebeplere başvurması yazıllyordu. ${ }^{71}$

$\mathrm{Bu}$ etkin sebepler arasında, gasp edilmiş tuzun nakit cezasıyla birlikte Osmanlı ordusunun desteğiyle tahsil edilmesinden başka bir şey yoktu. 1863 yılında ortaya çıkardıkları karmaşadan ötürü Garzan ve Şirvan müdürleri Hamid ve Osman Beylerin eyalet merkezine gitmeyi kabul etmeleriyle Pervari civarındaki tuzlalar meselesi barışçll bir şekilde çözülmüştü. Bu bölge haricindeki tuzlaları kapsayacak operasyona ilişkin 1864 baharında Meclis-i Vala'da gerçekleşen müzakerelerde, Siirt tuzlalarının zapta girmesinin Melefan tuzlasının kontrole girmesine bağlı olduğu belirtiliyordu. Kaymakam Abdülkadir Bey ve Siirt tuzlalarının da bağlı olduğu Halep Rüsumat Nezaretindeki memurlanın önerilerini içeren tartışmada, operasyona ilaveten tuzladaki memur sayısının artırılması, gerektikçe geçici surette zabitan istihdamı ve tuz muhafazası için ambar ve memur ikametgahı için özel alanlar inşası ve "aşiret gözünde hafif görünmemek için" muktedir bir müdür tayin edilmesini öneriyordu. Bu bağlamda Zırki tuzlasının idari olarak Muş’a bağlı olmasının da askerî müdahalelerde sebep olduğu karmaşanın giderilmesi için, bu tuzlanın da Siirt tuzlalarına bağlanması düşünülmekteydi. ${ }^{72} \mathrm{Bu}$ tartışmaların yanında Muş kaymakamı, tuz hırsızlarının çoğunu teşkil eden -Nuh Bey’in çevresinden

69 “Tuz Nizamnamesi ve Zeyli”, s. 694. Sürecin Meclis-i Vala'daki tartışması için bkz. BOA. İ.MVL 495/22418, 25 Cemaziyelevvel 1280 (7 Kasim 1863).

70 BOA. İ.MMS 28/1206, 9 Şevval 1280 (18 Mart 1864).

71 BOA. A.MKT.MHM 294/90, 12 Şevval 1280 (21 Mart 1864); BOA. A. MKT. MHM. 295/90, 25 Şevval 1280 (3 Nisan 1864).

72 BOA. MVL 662/2, 10 Şaban 1280 (20 Ocak 1864); 
olan- Şirvan ve Garzan'daki göçer ve yerleşik halkı bir tarafta Sürt'ten diğer tarafta Muş’tan abluka altına alacak bir planı Osmanlı hükümetine sunmaktaydı. ${ }^{73}$ Nisan ayının da gelmesiyle yolların açıldığını belirten kaymakam, Muş'un aşiretlerinden topladığ1 400 süvari ve 2 bölük piyade ile tuz hırsızlarının peşine düşmek için İstanbul'dan izin talep etmekteydi. ${ }^{74}$

Kürdistan valisi Siirt'teki tuzlalara dair raporunda ise bölgedeki sorunun kaynağına işaret etmişti. Tekele rağmen, tuzlaların sahibi olan ahalinin "hâlâ memlehaları kendi malları" bilmesinden şikâyet eden vali, tuz fiyatı, tuz işçilerine ve nakliyesine verilen ücretin bölgedeki kişilerce anlaşılmadığının altını çizmişti. ${ }^{75}$ Başka bir deyişle, vali "ücret-i nakliye ve ihraciye" gibi maliyet masrafları dişında tuzun ayrı bir fiyatı olmasına halkın tepki gösterdiğini ve bu tutarın "tuz bahası değildir ücrettir" şeklinde anlatılması gerektiğini belirtmekteydi. Vali, bu karmaşa haricinde tekelin bölgede tesisiyle memurların belirlediği okkada 3 para nakliye ve ihraciye ücretine halkın razı olmadığını dile getirmekte ve tuzlalar ile ambarlar arasında mesafe gözetilmeksizin bu ücretin 4,5 paraya çıkarılmasını elzem görmekteydi. Birkaç sene sonra yayınlanmış Diyarbekir salnameleri, valinin bu önerisinin gerçekleştiğini göstermekte. ${ }^{76}$

Bir yandan devam eden askeri operasyonlar eşliğinde 1864 yazında Siirt'teki tuz tekelinde birtakım idari değişiklikler de hayata geçmişti. Tuz işçilerinin aldıkları ücrete yapılan zam yanında Siirt tuzlalarını da kapsayan Diyarbekir tuzlaları Halep Rüsumat Nezareti'nden ayrılmış ve Diyarbekir'deki müstakil müdüriyetin başına aylık maaşının 2.955 kuruştan 5.000 kuruşa çıkarılmasıyla - bir müdür tayin edilmişti. ${ }^{77} \mathrm{Bu}$ idari değişikliği, ilerleyen operasyonlarda yetki alanlarını daha belirgin kılmak için Zırki nahiyesinin Muş’tan ayrılarak Siirt'e bağlanması takip etmişti. $^{78}$

Bu gelişmelerin yanı sıra 1864 yazında Abdülkadir Bey’in kumandasında Zırki ve Siirt tuzlalarında çalınan tuz ve nakit ceza tahsili için girişilen askeri operasyonda öncelikle Siirt'te Haçkan ve üç beş tuzla daha ortaya çıkarılmıştı. ${ }^{79}$

73 BOA. MVL 669/89, 4 Zilhicce 1280 (11 Mayıs 1864).

74 BOA. MVL 675/20, 13 Muharrem 1281 (18 Haziran 1864).

75 BOA. İ.MVL 912/23098, 14 Safer 1281 (19 Temmuz 1864).

76 Salname-i Vilayet-i Diyarbekir, defa 6 (1288 [1871]), 142-48. Ayrıca bkz. BOA. MVL 681/107, 13 Rabiulahir 1281 (15 Eylül 1864).

77 Müdür olarak Trablusgarp eski tütün müdürü Kamil Efendi atanmıştı. Müdürün maaşıyla birlikte bir bașkatip, bir sandık emini, bir mukayyit ve bir ikinci katip de istihdam edilen yeni idarenin aylık bütçesi 8.300 kuruşa çıkmıştı. BOA. İ. MVL 912/23098, 14 Safer 1281 (19 Temmuz 1864); BOA. MVL 677/106, 2 Safer 1281 (7 Temmuz 1864).

78 BOA. MVL 677/31, 26 Muharrem 1281 (1 Temmuz 1864).

79 Haçkan aşiretinden çalınan tuzun bedeli ve cezasını içeren 522.915 kurușluk bir tutarın tahsil edildiği, bunun 1.703 kuruşunun nakliye masrafi, 9.392,5 kuruşunun da operasyona katılan aşiret reisleri ve muhtarlara ve hayvanlarına yapılan masraf olduğu belirtilmekteydi. BOA. MVL 
Zırki tuzlasından çalınan tuzlardan 364 bin kuruş civarında bir tahsilat yapılmış, bunun 135 bin kadarının Abdülkadir Bey’in asker maaşlarına ayrılması sonrasında 208.422 kuruş ise Rüsumat Emaneti'ne gönderilmişti. ${ }^{80}$. Operasyon sonunda, Dördüncü Ordu'nun 5. Hafif piyade alay1 3. Taburu bölüklerinden 45'er kişilik alt1 takımdan ikisi Siirt'te yerleştirilmişken, tuzlaların da çavuş ve onbaşı kumandasında üç beş neferle muhafazası düşünülmekteydi. Fakat bölüğü dağıtmanın zararlarının dile getirilmesiyle, bu altı takım yerine 5. Hafif piyade alayı Siirt'e sevk edilmiş ve Siirt'te tuzlaların asker ile korunma dönemi başlamıştı. ${ }^{81}$

Askeri operasyonun asıl hedeflerinden biri ise tuzlaların tekele devrindeki en büyük engel olan Nuh Bey'in etkisiz hâle getirilmesiydi. Zırki tuzlasındaki zimmeti dolayısıyla görülen ve 1867'de sonlanan dava dosyası sayesinde mirin 1864 y1linda tutuklanarak Diyarbekir'e götürüldüğü anlaş1lyor. ${ }^{82}$ Operasyon sırasında Bitlis kaymakamının kendisine yönelik başarısız yakalama girişimi sonrasında, Nuh Bey önce tuzladan zimmetine para geçirmiş sonra da tuzla memurlarını kaçırarak üretilen tuzun "meydanda kalmasına" sebep vermişti. Osmanlı hükümetinin Zırki tuzlasını tekele dâhil edebilmek için "kefilsiz" istihdam ettiği Nuh Bey'in mahkeme sırasında 21,757 kuruş zimmeti çıkmıştı. Mirin bu tutarın 16,570 kuruşluk kısmını ödemeye muktedir olmadığını belirtmesi ve sonrasında Rüsumat Emaneti'nin mirin malvarlığına yönelik araştırması sonucunda "emlak ve akarı" olmadığının ortaya çıkmasıyla bunun tahsilinden vazgeçilmiş ve kendisi Vidin’e tekrar sürülmüştü.

Zırki tuzlasından çalınan tuzların cezasının tahsili meselesi ise çok daha çetrefilli bir meseleydi. Öncelikle çalıntı tuzları kaydeden eski Diyarbekir tuzla memuru Safveti Efendi defteri düzgün ve adil tutmamış ve bu da çalıntı tuz miktarını akıl almaz seviyelere çekmişti. ${ }^{83}$ Elbet bu Osmanlı tuz tekelinin Siirt özelinde sorunlu bir şekilde işlediğine dair bir mesele olsa da Siirt meclis azaları çalınan tuza dair bölgenin gerçeklerine uygun gerçekçi bir bakış açısı sunmaktaydı. Meclis azaları, "meydanda kalan tuzları herkes istediği gibi çekip götürmüş" olduğu için "her birinin derdestlerine kıyam olunsa" bile bunun hem memurlarca büyük bir tahkikat gerektireceğini hem de çok zaman alacağ1 sebebiyle tuz gasp edenlerin

681/107, 13 Rabiulahir 1281 (15 Eylül 1864); BOA. MVL 686/48, 17 Rabiulevvel 1281 (20 Ağustos 1864); BOA. İ.MVL 533/23929, 25 Muharrem 1282 (20 Haziran 1865).

80 BOA. A.MKT.MHM 326/4, 7 Şevval 1281 (5 Mart 1865).

81 BOA. A.MKT.MHM 317/13, 6 Cemaziyelahir 1281 (6 Kasım 1864).

82 BOA. A.MKT.MHM 387-B/16, 19 Receb 1284 (16 Kasim 1867).

83 Safveti Efendi'nin kendisinin hazırlamayıp tahkik memuru mülazım Süleyman Ağa’nın hazırladığı iddia edilen bu defterde sadece gasp meselesi kendi beyanına dayanmakla kalmamıs ayrıca tuzu gasp etmekle itham edilenlerin de vergilerinin tahsilatının ertelenmesi kararlanmış olan göçebe aşiretler olduğu ortaya çıkmıştı. Bu deftere göre Zırki tuzlasından çalınan tuz miktarı 1.165.464 okka, tuzun ederiyle birlikte nakit cezası yaklaşık 1.747.000 kuruş idi. BOA. MVL 688/17, 4 Cemaziyelevvel 1281 (5 Ekim 1864); BOA. MVL 679/106, 8 Cemaziyelevvel 1281 (9 Ekim 1864); BOA. A.MKT.MHM 387-B/16, 19 Receb 1284 (16 Kasım 1867). 
peşine düşülmesinin anlamsız olduğunu belirtmişlerdi. Buna bir de son üç senedir tekrar baş göstermiş olan çekirge istilasını ekleyerek, asker için gerekli erzak ve levazımatının tedarikinde bile zorluk çekileceğini ifade etmişlerdi. ${ }^{84}$

Nuh Bey’in parçası olduğu aşiret ağalarını da kapsayan bu ilişki ağı dağıtılsa da bu, tekelin aşiretleri kullanmasının sona erdiği anlamına gelmiyordu. Örneğin, Osmanlı yetkilileri Melefan, Sulha ve Sason tuzlalarındaki işçilerin ihraciye ücretinden fazla aldıkları maaşların tahsil edilebilmesi için bazı aşiret ağalarını kullanmış, bu tahsilatın da bir kısmını ağalara mükafat olarak ayırmışt1. ${ }^{85}$ Siirt'teki tekelin aşiretleri tahsilat işinde kullandığı bu örnekler olurken, bir yandan da tekelin işlerliği adına birtakım yenilikler daha yürürlüğe girmişti. Siirt tuz memurlarının yerli eşraftan olmasının vahim sonuçlarının tecrübe edilmesiyle Temmuz 1865'te Meclisi Vala'da Diyarbekir'deki tuzlalara dair bir müzakerede, memurların eşraftan olması ve tuz işçileriyle ittifak etmesinin olası zararlarından bahsedilmişti. Nuh Bey ve ilişki ağ1 düşünüldügünde pek de yadsınamayacak bu durum karşısında, Diyarbekir tuz memurlarına tahsis edilmiş olan toplam bütçe yüzde elliden fazla bir artışla aylık 43,890 kuruşa çıkarılmıştı. ${ }^{86}$ Tuz memurlarına yönelik bu iyileştirmeyi ise 1866 'da tuz müşterilerine yönelik bir başka gelişme takip etmekteydi. Tuzlaların Diyarbekir'e uzaklığından ötürü artan nakliye maliyetleri sonucunda tuzun yüksek fiyatlarla satılmasına karşı Meclis-i Vala eyaletin dört yerinde tuz ambarı inşası planlanmışt1. ${ }^{87}$ Her ne kadar bu dört ambardan sadece birinin inşa edilmesine karar verilmişse de yine de bu ambarın vilayet dâhilindeki tuzun fahiş fiyatla satılmasını engelleyeceği düşünülmüştü. ${ }^{88}$ Elbette ambarların inşasıyla genellikle Reji dönemiyle anılan kolcular da ortaya çıkmıştı. Diyarbekir'deki ambarda iki kolcu istihdam edilmişken 1867'de Rüsumat Emaneti'nin talebi doğrultusunda bir sergerde, beş yüzbaşı ve yedi çavuşun da bulunduğu 139 kişilik bir kuvvet

84 Bölgede benzer bi çekirge istilası için, bkz. Zozan Pehlivan, "Abandoned Villages in Diyarbekir Province at the End of the 'Little Ice Age', 1800-50", The Ottoman East in the Nineteenth Century: Societies, Identities and Politics, ed. Tolga Yaşar Cora, Ali Sipahi ve Dzovinar Derderian (Londra ve New York: I.B. Tauris, 2016), 240.

85 Mükafat Osmanlı pratiklerinden biri olan hil' at bahasıydı ve ele geçirilen tuzun nakliye ücretiyle birlikte 18.699 kuruşu bulmuştu. BOA. İ.MVL 553/24822, 8 Muharrem 1283 (23 May1s 1866).

86 Bu artışın fazlalığın farkında olan meclis azaları, tekelin başlangıcında sorun çıkarmış olan "aşiret" sorunu artık çözülmüş ve bu aşiretlerden toplanan 750 bin kuruşluk bir tahsilat olmasını bir gerekçe olarak sunmaktaydı. BOA. MVL 710/7, 18 Safer 1282 (13 Temmuz 1865).

87 Bu ambarda aylık 500 kuruş maaşla iki sevk memuru ve bir müdür, 350 kuruşla bir sandık emini ve bir katip ve de 100 kuruşla iki kolcu ve bir kantarcı çalışacaktı. BOA. MVL 1043/2, 9 Receb 1283 (17 Kasim 1866).

88 Benzer bir şekilde, tuz ambarları Rus İmparatorluğu'ndaki tekelde de mevcuttu. 1781'de çıkarılan Tuz Kanunundaki en asli yeniliklerden biri her idari bölgede iki yıllık tuz arzını sağlayacak tuz ambarlarının tesisiydi. John P. LeDonne, "Indirect Taxes in Catherine's Russia I. The Salt Code of 1781", Jahrbücher für Geschichte Osteuropas 23, no. 2 (1975): 173. 
Kürdistan eyaleti tuzlalannı "tam” muhafaza etmek için istihdam edilmişti. ${ }^{89}$

Rüsumat Emaneti'nin askeri yöntemlerle desteklediği tekele hukuki gelişmeler de eşlik etmekteydi. Tuz müşterisini dolaylı bir şekilde tekelin sürekliliğini sağlayacak bir fail kılan hükümet, 1862 Nizamnamesinde kaçak ve çalıntı tuzları ihbar edenlere verilen ödül ödemesini 1866'da daha da kapsamlı hâle getirmişti. Tuz kaçakçılığı veya hırsızlı̆̆ı durumunda zanlıların firar etmesi ya da nakit cezayı ödeyememesi durumunda "muhbirlerin mükafatsız birakılması"nın ihbarların etkinliğindeki olası düşüşünü değerlendiren Meclis-i Vala, tekelin devamı için yeni bir pratik yürürlüğe koymuştu. Nakit cezanın ödenemediği bu durumlarda, yetkililer ele geçirilen tuzu satacak ve yarısı devlete gelir olarak kaydedilirken diğer yarısı da ihbariye bedeli olarak bu vakayı haber verenlere ödenecekti. ${ }^{90}$ Elbet bu durum, halkın arasından muhbirler çıkararak tüketicileri aynı zamanda tekelin bir parçası kılmakta ve dünyadaki diğer tekellerde de görülecek bir uygulamaya yol açarken öte yandan halkın bu durumdan kolay paralar kazanmasını sağlamaktaydı. Örneğin 1866'de Zırki tuzlası memurlarından Şaban Ağa, bölge aşiretlerinin beş bin katır yükü civarında tuzu gasp ettiğini iddia etmiş ve "ihbariye almak efkarıyla" okuma yazma bilmeyen meclis azalarından bu hırsızlığ1 zapt altına almıştı. ${ }^{91}$ Diyarbekir tuzla memuru ve Siirt kaymakamının yerinde gerçekleştirdikleri araştırma sonrasında ise Şaban Ağa'nın tutturduğu zabıttaki tutarı "mübalağalı" bularak çalınan tuzun 6 yük civarında olduğunu belirtmişlerdi. Yakın zamanda bölgede bu boyutta bir gasp olmadığına kanaat getiren yetkililer, bu çalıntı tuzları

120 yağmur ve sel etkisiyle kaya tuzlarının zuhur etmesine bağlamış ve sonuç olarak Şaban Ăğa'yı suçlu bulmuştu.

\section{Tekel, Yoksulluk ve Şiddet}

Osmanlı tuz tekeli, sadece tuz gibi temel bir ihtiyac1 meta haline getirerek Osmanlı tebaasını müşteri haline getirmemiş ayrıca askeri ve hukuki pratiklerle de kolcu ve muhbirler ortaya çıkararak yeni toplumsal dinamikler ortaya çıkarmıştı. ${ }^{92}$ Bu dinamiklerin başında tahmin edilebileceği veçhile kaçakçılık geliyordu. Osmanlı topraklarında kaçakçllık elbette yeni bir şey değildi. 16. yüzyıldan itibaren Avrupa'nın artan talebi karşısında yükselen fiyatların tetiklediği veçhile hububat ve hammaddelerin kaçak şekilde ihracı bilinen bir olgu. Osmanlı hükümetinin 17. ve 18. yüzyıllar boyunca kıtlık ve iç üretimin sınırlı kaldığı dönemlerde belirli tarımsal malların ihracatını yasaklamasına rağmen, bunun Osmanlı tüccarlarıyla birlikte

89 Bahsedilenler dışında, zabitlerle birlikte bir katip ve 70 nefer piyade de mevcuttu. BOA. İ.MVL 575/25085, 12 Safer 1284 (15 Haziran 1867).

90 BOA. İ.MVL 558/25069, 8 Rabiulahir 1283 (20 Ağustos 1866).

91 BOA. MVL 746/34, 8 Cemaziyelevvel 1283 (18 Eylül 1866).

92 Kolcuların hayatlarına dair bir fikir vermesi için bkz. Ahmet Yüksel, "Türkiye'de Tütüncülerin Kaçakçlaşma Sürecinde Kolculuğun Baskısını İki Kolcunun Tercüme-i Halinden Anlama Denemesi", Kebikę̧, no. 34 (2012).185-200. 
çalışan Avrupalı tüccarlar aracılığıyla gerçekleşen kaçakçılığı önlemeye yetmediği söylenebilir. ${ }^{93} \mathrm{Bu}$ hususta 18 . yüzyıldan itibaren Selanik başta olmak üzere Balkanlardan gerçekleşen tütün ihracatı ise ayrıca öne çıkmaktaydı. Tütün tarımı ve ticaretinde 1609 gibi erken bir tarihte başlayan kaçakçılık ile Osmanlı hükümetinin farklı kısıtlama tedbirlerini izleyen mücadelesi 17. yüzyıl sonunda imparatorluğun birçok bölgesinde kurulmuş gümrük noktaları ile devam etmişti. ${ }^{94}$ Genellikle piyasa koşullarına göre şekillenen ve erken modern dönemdeki farklı bölgeler arasındaki fiyat dalgalanmalarının da etkili olduğu bu tür kaçakçlık örnekleri ile k1yaslandığ1nda, üretim maliyetlerinin düşüklüğü ve Osmanlı topraklarındaki nakliye koşulları düşünüldüğünde karlılığı çok az olacak tuz, kaçakçılık için ticari bir meta olmaktan uzakt1.

Tekel öncesinde, sıklıkla nakliye ve ticaretini üstlenmiş mültezimler de gözettiği belirli düzeydeki kârlılık ile tuzu müşterilerine satmaktaydı. Fakat tekel sonrasında tuz, piyasa koşullarına göre alınacak bir meta olmaktan çıkmış ve Osmanlı Maliyesinin bütçe açı̆̆ını düzenlemek üzere fiyatlandırabileceği bir meta halini almıştı. Tüketim ayağından bakıldığında, tekelin Osmanlı tebaasını devletin belirlediği fiyatların çok altında satın alabilecekleri - özellikle deniz yoluyla gelen "kaçak" tuza yönlendirmiş olduğu söylenebilir. 95 Temel bir ihtiyaç maddesini kurumun doğası gereği maliyetinden çok yüksek fiyatlara satan tuz tekeli, üretim ayağında da emekçileri çıkardıkları tuz üzerinden ayni maaş alma hakkından mahrum birakmaktaydı. Zira Meclis-i Mahsus'ta tuz tekelinin kurulmasına yönelik oturumların birinde, tuzlalarda çalışan reis ve emekçilerin - o vakte kadar her bölgenin kendi koşullarına göre şekillenmiş hâldeki - üretimden aldıkları hisselerini diledikleri fiyattan satma ihtimalleri göz önünde bulundurulmuş ve bu tekelin mantığına aykırı bulunduğundan tuz emekçilerine "mutedil ve münasip" maaşlar öngörülmüştü. ${ }^{96}$ Yılın belirli bir kısmıyla sınırlı olsa da tekelin Osmanlı tebaasının işçileşmesine yönelik bu husus bir yana, önceden çıkardıkları tuz üzerinden bu ihtiyaçlarını karşılamış tuz emekçileri de tekel ile müşteriye dönüşmüştü.

Bu bağlamda, tekelin Siirt'te ortaya çıkardığ1 tuz kaçakçılığ1 ve yoksulluk sarmalı görece yeni bir gelişmeydi. Osmanlı hükümeti de tuz tekelinin evrimi esnasında bu durumun biraz da farkında olarak nakit ceza yaptırımında esnemeye gitmişti. Zira, kaçakçıların yakalanamadığı durumlarda bu kaçakçılığı ihbar edenlere verilecek ihbariye bedeli müzakere edilirken Meclis-i Vala'daki Osmanlı yetkilileri, tezkeresiz yakalanan kaçak tuz ve tütün zaten müsadere olunmuşken bir de nakit

93 Şevket Pamuk, Osmanl-Türkije İktisadî Taribi, 1500-1914 (İstanbul: İletişim Yayınları, 2005), 111, 163.

94 Fehmi Yılmaz, "Osmanl İmparatorluğu'nda Tütün: Sosyal, Siyasî ve Ekonomik Tahlil (16601883)" (Doktora Tezi Marmara Üniversitesi, 2005), 127-32.

95 Osmanlı Devleti'nin bilhassa Ege'deki uzun kıylları tuz kaçakçllı̆ı için mükemmel firsatlar sunmaktaydı. Blaisdell, European Financial Control, 109.

96 BOA. İ.MMS 24/1028, 24 Cemaziyelevvel 1278 (27 Kasım 1861). 
ceza tahsiline girişmenin adil olmayacağ1 kanaatindeydi. ${ }^{97} \mathrm{Bu}$ şekilde kaçak tuz ve tütünle yakalananlardan nakit ceza tahsilinden vazgeçilmişti. Fakat bu "adil" uygulamanın tam tersi yönünde Kasım 1866'da Diyarbekir'de tuzlalar haricinde satılacak tuza bir kez daha zam gelmiş, nakliye masrafiyla birlikte okkada 60 paraya, yani 1,5 kuruşa çıkmışt1. ${ }^{98}$

Tuzla haricinde yaşayan ve tuzu tüccardan almak zorunda kalan tekel müşterileri için bu fiyat artışı karşısında kaçak tuza rağbet etmemelerini beklemek anlamsız olurdu. Nakit cezasinın kaldırılması zaten halkın daha ucuz olan tuza erişim ihtiyacına işaret ederken bir yandan da Osmanlı tekel memurlarını da düşen gelirler konusunda endişelendirmekteydi. Zira önceden el konan tüm tuzun ederini ihbariye olarak alan muhbirler, bu cezanın kaldırılmasıyla birlikte sadece bu yekunun yarısıyla iktifa etmek durumundaydı. Hâliyle bu durumun muhbirleri pek de teşvik etmediğini dile getirmiş olan Rüsumat Emaneti, tuz ve tütün kaçakçılarından mallarının müsaderesinden başka ceza almanın hakkaniyetli olmayacağının da farkında olarak tuz kaçakçılığını gümrükten mal kaçırma ile kıyaslayarak mevcut hukuki yaptırımların hafifliğine işaret ederek nakit cezanın geri dönüşünü meşrulaştırmıştı. "Tuz kaçıranların zaten kıymeti lâş [düşük] makulesi olan tuzlarının yalnız zaptından gayrı ihtiraz edecek meydanda bir şey kalmaması"nın altını çizen Emanet yetkilileri, "iki üç kere tuzları tutulup da dördüncü defa tutulması"nda yine yakalanmamaları durumunda ciddi bir kazanç elde edebileceklerini belirtmekteydi. ${ }^{99}$

Altı aylık bir deneme sürecinden sonra Mart 1867'de geri gelen nakit ceza uygulaması, tekelle birlikte pek anılmayan yoksulluk ilişkisini de gözler önüne seriyor olsa gerek. Tüketimin vergilendirilmesi kapsaminda Osmanlı hükümetinin bu dolaylı vergi üzerinden yoksul kesimlerin - kapsamı belki k1sıtlı olsa da yoksulluklarını derinleştirmesinin yanında Siirt'teki tuzla çalışanlarının tekele doğrudan bağlı başka bir yoksulluk dinamiği daha mevcuttu. Tuz tekelinin 1867 yılında Melefan tuzlasındaki depolarda mevcut tuzun satışını öncelikli hâle getirmesi ve o yıl için üretimi durdurmasıyla Melefan civarındaki tuz işçileri buna karşı çıkmıştı. Tüketim yanında yazlarını tuz tekeli için çalışarak geçiren tuz işçilerinin buradan alacakları mevsimlik maaşlar oldukça önemli bir yer tutmaktaydı. Dilekçelerdeki evrensel abartı payı göz önünde bulundurularak Müslüman ve Hristiyan işçileri temsilen iki kişinin imzasıyla yazılan dilekçeye bakıldığında, Melefan tuz işçileri tekelin tek geçim kaynakları olduğundan, tuzla açılmazsa yevmiyeye muhtaç olacaklarından ve başka bir yere göç etmek zorunda kalacaklarından bahsederek tuzlanın işletilmesini talep etmişlerdi. ${ }^{100}$ Melefan ve

\footnotetext{
97 BOA. İ.MVL 558/25069, 8 Rabiulahir 1283 (20 Ağustos 1866).

98 BOA. MVL 1043/2, 9 Receb 1283 (17 Kasim 1866).

99 BOA. İ.MVL 569/25571, 18 Zilkade 1283 (24 Mart 1867).

100 BOA. MVL 1047/31, 18 Rabiulahir 1284 (19 Ağustos 1867).
} 
Sason tuzlalarındaki ahalinin muhalif hareketlerinin bastırılması için asker sevk etmeyi planlayan Osmanlı hükümeti ise bu gelişme sonrasında bunu ertelemiş ve bölgedeki halkın "zaruret ve havayıcını defe kâfi olacak kadar tuz çıkarılmak üzere" tuzlaları açmışt1.

Siirt tuzlalarındaki yoksulluk sarmalı tuzla işçilerinin işlerinden olması tehlikesinden ibaret değildi. Tuz kaçakçıllğı elbette Siirt bölgesine has bir olgu değildi fakat Siirt'in sosyoekonomik durumunun tetiklediği yoksulluk karşsısında, tuzlalardan ambarlar nakliye sırasında eksik çıkan tuzların gerek aynen gerekse de nakden toplanmasının yol açtığı borç yükü başka bir sıkıntıya işaret etmekteydi. Tuzlaların tekele geçtiği dönemde, ihraciye ücretinin yanında aldıkları nakliye ücretinin -tuzları nakletmedikleri gerekçesiyle- Melefan tuzla işçilerinden maaşlarından kesinti suretiyle tahsil edilmesinin yanı sıra Diyarbekir valisi Mart 1870'de Babıali'ye yazdığ1 bir mektupta Sason ve Siirt bölgesindeki halkın bu borçları ödemekte çektikleri zorluktan bahsetmekteydi. ${ }^{101}$ Nakledilmediği iddia edilen tuzların akıbeti belirsiz olsa da vali "idare-yi beytiyelerinden" yani ev idarelerinden yoksul oldukları anlaşılan kimi Melefanlıların üzerinde 150 bin kuruştan fazla nakit ceza bakiyesi olduğunu belirtmişti. Ayrıca, Melefan tuz işçilerinin maaş karmaşasından ötürü aldıkları ihraciye ücretlerinden kesintiler sayesinde yaklaşık 23 bin kuruşun tahsil edildiğini ifade etmiş ve bazı yoksulların da zimmetlerinin "gelecek sene hasıl olacak ücret-i ameliyelerinden istifa olunmak üzere taahhüt"e bağlandığının altını çizmişti. ${ }^{102}$ Yoksulluğun vardığı raddeyi tasvir eden valinin bu yazısı sonrasinda Meclis-i Mahsus tahsil edilecek tüm ceza ve ödemelerin affedilmesine ve o ana kadar ödedikleri meblağın da kendilerine iade edilmesine karar vermişti.

Osmanlı hükümetinin tuz özelinde tüketimi vergilendirilebilir hâle getirmenin sonuçlarını bu tür uç örneklerde hafifletecek girişimlerden geri durmadığ1 söylenebilirse de Siirt gibi kimi bölgelerde kaçakçıllk-yoksulluk ilişkisinde tekelin fiziksel şiddetten aldığı destek, idari ve hukuki yeniliklerle de hâlâ destekleniyordu. Siirt başta olmak üzere tuzla gelirlerinin yönetiminde büyük kolaylık sağlamış olan Diyarbekir Tuz Müdüriyeti, Aralık 1867'de o vakte kadar Halep Nezaretinin üstlendiği bölgedeki diğer dolaylı vergilerin tahsilinden de sorumlu olacak şekilde Diyarbekir Rüsumat Nezaretine dönüştürülmüştü. Söylem düzeyinde bu idarenin yapılanmasının ardında bölge halklarının "mizaç ve kaide bilmez birtakım Kürt ve aşiretten ibaret olması" ve diğer dolaylı vergilerin tahsilinde Halep'ten gönderilen "küçük maiyet memurlarının ahalinin gözlerini dolduramaması" dile getirilmişse de bunu Osmanlı tekellerinin Düyun-1 Umumiye

\footnotetext{
101 Melefan tuzlasında işçilerin 1861 ve 1862 yllarında fazladan aldıkları nakliye ücreti tutarı 1864'ten 1868'e kadar maaşlarından kesilmişti. BOA. ŞD 1452/49, 8 Cemaziyelevvel 1287 (6 Ağustos 1870).

102 BOA. İ.MMS 38/1589, 18 Zilhicce 1286 (11 Mart 1871).
} 
öncesinde uzak vilayetlerde de etkin bir yaygın idare kurmaya başladı̆̆ının bir veçhesi olarak görmek gerekir. ${ }^{103}$

1870’lerde gerçekleşen kimi hukuki değişiklikler de tekellerin etkinliğini artırmaya yönelikti. Tuz Nizamnamesinin 22. bendinde yapılan tadille Osmanlı sınırları ötesinden ithal edilen tuzlar da devlet sınırları dâhilindeki gibi kaçakçılık muamelesi görecek ve bu kaçakçılar da tuzun fiyatının iki katı tutarında nakit ceza ödeyecekti. Üstelik bu ceza, ülkeye bu şekilde kaçak sokulmuş ve yakalanmış tuzları değil tüketilmiş olanları da kapsıyordu. ${ }^{104}$ Tüketilmesi sonrasında haberi alınmış kaçak ithal tuzlar için nakit ceza, yerel meclislerce belirlenecek ve bu cezay1 ödemeyenler de üç aylık hapse çarpılacaktı. ${ }^{105}$ Rüsumat Emaneti, tuz ithalatını yasaklayan anlaşmanın İran'la henüz imzalanmadığını belirttiği yazıda Şura-yı Devlet'ten İran sınırından ve Diyarbekir vilayetinde henüz tekele alınmamış tuzlalardan aşiretlerce Osmanlı topraklarına sokulan kaçak tuzların menedilmesini talep etmekteydi. ${ }^{106}$ Bunun sonucunda, 1874'te çıkarılan bir kanunla Osmanlı topraklarına kaçak tuz sokanlar da ülke içindeki kaçakçılar gibi nakit ceza ödeyecek ve bu nakit ceza ihbariye olarak muhbirlere ödenecekti. Kaçak tuz sahibinin firarı ya da cezayı ödeyecek maddi durumunun olmaması sebebiyle hapse girmesi durumunda yakalanan tuzun çeyreği muhbirlere aynen verilecekti. ${ }^{107}$

Başarılı olup olmadığının ötesinde toplumsal bir bakış açısıyla ele alındığında Sïrt'teki tuz tekelinin oluşum ve gelişim sürecinin şiddet ile iç içe geçmiş bir yoksulluk dinamiğini ortaya çıkardığı söylenebilir. Çok sıklıkla Düyun-1 Umumiye 124 İdaresi'ne atfedilen "sömürgeci" olarak ayrica ele alınan şiddet, Reji İdaresi'nden önce Osmanlı tuz tekelinin kendisinde mevcuttu. Literatürde s1klıkla dile getirilen bir söylem olarak Reji'nin kaçakçllıkla mücadelede yetersiz insan gücüne karş1 Osmanlı Devleti'nden askeri destek istemesi ve Osmanlı yetkililerinin kaçakçllıkla mücadeleyi Reji'ye bırakarak usulen reji memurlarına refakatle görevli jandarmalar temin etmesi, Diyarbekir Rüsumat Nezareti'ni devralan Düyun-1 Umumiye ile Osmanlı Devleti arasında defalarca gerçekleşmişti. ${ }^{108}$ Bu bağlamda, 1884'ün tuz üretimi mevsiminde Düyun-1 Umumiye’nin “önceki iki yılda olduğu” gibi Melefan tuzlasında güvenliğin sağlanması için Osmanlı askeri istemesi ve buna karşıllk

\footnotetext{
103 BOA. İ.MVL 582/26165, 22 Şaban 1284 (19 Aralık 1867).

104 “Tuz Nizamnamesi ve Zeyli”, 699. Ayrıca bkz. BOA. İ.DH 1295/101725, 3 Ramazan 1286 (7 Aralik 1869).

105 BOA. ŞD 555/10, 17 Rabiulahir 1288 (6 Temmuz 1871); Demirel, "Osmanlı Devleti'nde Tuz", 153.

106 BOA. HR.MKT 826/87, 17 Safer 1291 (5 Nisan 1874). BOA. İ.MMS 49/2097, 10 Rabiulahir 1291 (27 May1s 1874).

107 “Gerek Yerli ve Gerek Ecnebi Mahsulü Kaçak Tuzları Tutan veyahut Haber Verenlere İta Kılınacak İhbariyeye Dair Fıkarat-1 Nizamiyedir”, Düstur, Tertip 1, Cilt 3 (İstanbul, 1293 [1876]), s. $369-70$.

108 Quataert, Osmanl Devleti'nde Avrupa, 33-35.
} 
olarak Seraskerlikten bu işin jandarmayla halledilmesi beyanı 19. yüzyılın son çeyreğinden 20. yüzyılın ilk on yilına kadar neredeyse her tuz mevsimi öncesinde gerçekleşecek taleplerin ilk örneklerin biriydi. ${ }^{109}$ Gerek Osmanlı döneminde gerekse 1881 sonras1 Düyun-1 Umumiye döneminde tekelin sivil veya askeri olarak mücadele etmiş olduğu kaçakçıllğın ardında ise güçlü bir yoksulluk yatmaktaydı. 1970’lerde hâlâ işleyen Siirt tuzlaları için “maliyetin çok yüksek olmasina rağmen sosyo-ekonomik durum bu tuzlaların kapatılmasına imkân vermeyecektir" diyen İlter'in altını inceden çizdiği yoksulluk elbette sadece Osmanlı tuz tekelinin sonucu değildi. ${ }^{110}$ Ancak tuzun çıkarılması haricinde başka bir ücrete tabi olmasına karşı direnmiş, kaçak ve daha ucuz bir tuz için mücadele vermiş insanlar için tekel, Siirt'te şiddet, istihdam kapısı ve borç zincirinin başka bir halkası idi.

\section{Sonuç}

Tekeller Düyun-1 Umumiye’ye ait bir kurum değildi. Tuzun temel bir ihtiyaç olduğu, kimya sanayisinin olmadığı bir ekonomide tüketiminin kayda değer bir artış göstermemesi ve çıkarılan tuzun da nakliye ve dağıtımındaki altyapı eksiklikleri sebebiyle Osmanlı tuz tekelinin yeterince kârlılık göstermediği tahmin edilebilir. ${ }^{111}$ Fakat mali başarısının ötesinde tuz tekeli bu bağlamda Osmanlı hükümetinin 19. yüzyıl boyunca çeşitli safhalarda veçhe değiştirmiş mali buhranlara karşı tuz gibi zaruri bir nesneyi dolaylı vergi kalemi kılarak yeni gelirler elde etmede yürürlüğe soktuğu bir uygulamayd1. 1862'deki kuruluşundan itibaren tuz tekeli Düyun-1 Umumiye'ye devredildiği tarih olan 1881'e kadar Osmanlı bürokratlarının müzakereleriyle şekillenen hukuki ve idari değişikliklerle kapsamını geliştirmiş ve ortaya çıkan sorunları çözmeye yönelik adımlar atmıştı. Elbet birçok vergi tahsilatında olduğu gibi dolaylı bir vergi olan tuz gelirlerinin tahsilatı da askeri yöntemlerin ve zorun devreye sokulmasıyla mümkün olabilmekteydi. Siirt tuzlalarında verilen mücadelelerin de gösterdiği veçhile, başta kaçakçılık olmak üzere tekele karşı direniş de Osmanlı topraklarında Düyun-1 Umumiye döneminden çok öncesinde başlamıştı.

Kaçakçılık her ne kadar tarihsiz bir mefhum olsa da Osmanlı tuz tekeli bu kaçakçılığa modern bir veçhe kazandırmakla kalmamış, aynı zamanda Osmanlı toplumundaki yoksulluk alg1sını da modern bir bağlamda görünür kılmıştı. Siirt'teki tuz tekelinin kaçakçllıkla giriştiği mücadelede hedef Kürt mirler ve bunlarla hareket eden aşiretler olmuştu. Gerek aşiretlerin tuzlalara yönelik saldırıları gerekse de tekelin tuzlaları muhafaza çabası karşılıklı bir şiddet izleğini ortaya çıkarmıştı. Ancak hem tuz çalmaya giden sürecin hem de Osmanlı ordusunun tuz gelirlerini tahsil için giriştiği askeri operasyonların ardında kesif bir yoksulluk yatıyordu. Siirt tuz tekeli, sadece tuz kaçakçıllğı yapan aşiretleri değil bizzat tuzlalarda çalışan

109 BOA. ŞD 298/33, 27 Zilkade 1301 (18 Eylül 1884); Demirel, "Osmanlı Devleti'nde Tuz", 152.

110 İlter, Türkiye'de Tuz Endiistrisi, İkinci Kitap, 67.

111 Adshead, Salt and Civilization, 157. 
işçilerin de geçim kaynaklarını derinden etkilemekteydi. Osmanlı valilerinin de fark ettiği şekilde kaçak tuzlardan sorumlu tutulmuş tuz emekçilerinin içine düştüğü borç bu yoksulluğu daha da perçinlemişti. Hukuki mevzuat ve bölgeye özel pratiklerle de desteklenen Siirt'teki tuz tekeli, çoklukla Düyun-1 Umumiye atfedilmiş, kaçakçıları askeri operasyonlarla yakalayan, Osmanlı tebaasının içinden kendi çıkarlarını kollayacak kolcu ve muhbir çıkaran "sömürgeci" idareden farksızd1. Aksine bu idarenin öncülü, Osmanlı tuz tekeliydi.

\section{Kaynaklar}

\section{Arşiv Belgeleri}

\section{Devlet Arşivleri Başkanlığı Osmanlı Arşivi (BOA)}

Sadaret Mühimme Kalemi Evrak1 (A.MKT.MHM), 239/71, 240/6, 245/2, 248/40, 263/22, 270/66, 271/46, 294/90, 295/90, 326/4, 317/3, 387-A/83, 387-B/16.

Sadaret Nezaret ve Devair Evrak1 (A.MKT.NZD), 178/38, 342/37, 404/97, 414/4.

Sadaret Umum Vilayat Evrakı (A.MKT.UM), 454/83.

Hariciye Nezareti Mektubi Kalemi (HR.MKT), 826/87.

İrade Dahiliye (İ.DH), 488/33013, 1295/101725.

İrade Hariciye (İ.HR), 102/4986.

İrade Meclis-i Mahsus (İ.MMS), 24/1028, 28/1206, 38/1589, 49/2097.

İrade Meclis-i Vala (İ.MVL), 438/19435, 481/21827, 482/21839, 482/21854, 495/22418, $533 / 23929, \quad 553 / 24822, \quad 558 / 25069, \quad 575 / 25085, \quad 569 / 25571, \quad 582 / 26165$, $912 / 23098$.

Meclis-i Vala (MVL), 649/74, 659/81, 662/2, 669/89, 675/20, 677/31, 681/107, 686/48, 688/17, 679/106, 710/7, 746/34, 1043/2, 1047/31.

Şura-y1 Devlet (ŞD), 298/33, 555/10, 1452/49.

\section{Yayınlanmış Kaynaklar}

Düstur, Tertip 1, Cilt 2 (İstanbul 1279 [1863]).

Düstur, Tertip 1, Cilt 3 (İstanbul, 1293 [1876]).

Salname-i Vilayet-i Diyarbekir, defa 6 (1288 [1871]).

\section{Diğer Kaynaklar}

Adshead, Samuel Adrian M, Salt and Civilization, New York 1992.

Altınay, Ahmed Refik, Osmanlı Devrinde Türkiye Madenleri, 967-1200. İstanbul 1931.

Atmaca, Metin, "Origins of the "Kurdish Question"? The Revolt of Yezdanşêr (1854-

1855)", The Routledge Handbook of the Crimean War, (ed. Candan Badem) Londra 2022, s. 357-70.

Balta, Evangelia ve Fehmi Yilmaz, "Salinas and Salt in Greek Lands during the Ottoman Period", Tuz Kitabı, (ed. Emine Gürsoy Naskali ve Mesut Şen), İstanbul 2004, s. 248-57.

Beşikçi, İsmail, Doğu'da Değişim ve Yapısal Sorunlar (Göçebe Alikean Aşireti), Ankara 1992.

Birdal, Murat, The Political Economy of Ottoman Public Debt: Insolvency and European Financial Control in the Late Nineteenth Century, Londra ve New York 2010. 
Blaisdell, Donald C., European Financial Control in the Ottoman Empire: A Study of the Establishment, Activities, and Significance of the Administration of the Ottoman Public Debt, New York 1929.

Cibo, Nezirê, Kürt Taribinde Garzan ve Pencinariler, İstanbul 2016.

Cihan, Ahmet, "Osmanlı Kanunnamelerinde Tuz ve Tuz Kültürü", Kamu Hukuku Arșivi Dergisi, 5/1 (2002), s. 1-6.

Cuinet, Vital, La Turquie d'Asie, géographie administrative : statistique, descriptive et raisonnée de chaque province de l'Asie Mineure, Cilt 2, Paris 1891.

Çağatay, Neşet, "Osmanlı İmparatorluğunda Maden İşletme Hukuku", AÜ DTCF Dergisi, 2/1, (1943): s. 107-16.

Çakır, Duygu, "Osmanlı Devleti'nin Son Döneminde Karadeniz'de Tuz Kaçakçllı̆̆1", Ordu Üniversitesi, Yüksek Lisans Tezi, Ordu 2019.

Çelik, Abdurrezzak, "XIX. Yüzyılın İkinci Yarısında Siirt Sancağının İdari ve Sosyoekonomik Durumu", Siirt Üniversitesi, Yüksek Lisans Tezi, Siirt 2019.

Demirel, Fatmagül, "Osmanlı Devleti'nde Tuz Gelirlerinin Düyûn-1 Umûmiye'ye Devredilmesinden Sonra Tuz Kaçakçlluğı", Yakın Dönem Türkiye Araştırmalar, s. 1, (2002), s. 147-57.

Dı̆̆ıroğlu, Filiz, Memalik-i Osmaniye Duhanlar Müsterekü̈l'l-Menfaa Reji Şirketi, İstanbul 2007.

Erim, Neşe, "18. Yüzyılda Erzurum Tuzları: Osmanlı Tüketim Malları Tarihine Bir Katkı." A.Ü. Türkiyat Arastirmalarn Enstitüsü Dergisi, s. 21, (2003), s. 219-29.

Genç, Mehmet, "Osmanlı Mali Sisteminde Tuz ve Tuzlaların Mahiyeti", Osmanl Devleti'nde Nebirler ve Göller, (ed. Şakir Batmaz ve Özen Tok), Kayseri 2015, s. 201-04.

Güçer, Lütfi, "XV-XVII. Asırlarda Osmanlı İmparatorluğu'nda Tuz İnhisarı ve Tuzlaların İsletme Nizamı", İstanbul Üniversitesi İktisat Fakültesi Mecmuası, 23/1-2 (1962-1963), s. 397-416.

Gürsoy Naskali, Emine ve Mesut Şen, ed., Tuz Kitabı, İstanbul 2004.

Hulkiender, Murat, Bir Galata Bankerinin Portresi George Zarifi 1806-1884, İstanbul: 2003.

İlter, Müfit, Türkiye'de Tuz Endüstrisi ve Tuz Ticareti, İkinci Kitap, Ankara 1980.

Kasım, Ekin, "Tuz Nizamnamesi Cerçevesinde 19. Yüzyılın İkinci Yarısında Osmanlı Devleti'nde Tuzlaların İdaresi ve İşletilmesi", Gazi Üniversitesi, Yüksek Lisans Tezi, Ankara 2016.

Kazgan, Haydar, "Düyun-1 Umumiye", Tanzimat'tan Cumburiyet'e Türkiye Ansiklopedisi İstanbul 1985, s. 691-716. , Galata Bankerleri, Cilt 2, Ankara 2006.

Kütükoğlu, Mübahat, "Tanzimat Devri Osmanl1-İngiliz Gümrük Târifeleri", Tarih Enstitüsü Dergisi, s. 4-5 (1973-74), s. 335-93.

Kwass, Michael, "Court capitalism, illicit markets, and political legitimacy in eighteenthcentury France: The salt and tobacco monopolies", Questioning Credible Commitment: Perspectives on the Rise of Financial Capitalism, (ed. Adrian Leonard, D'Maris Coffman ve Larry Neal), Cambridge 2013, s. 228-50.

LeDonne, John P., "Indirect Taxes in Catherine's Russia I. The Salt Code of 1781", Jahrbücher für Geschichte Osteuropas, 23/2 (1975), s. 161-90.

Özbek, Nadir, Imparatorluğun Bedeli: Osmanli'da Vergi, Siyaset ve Toplumsal Adalet (1839-1908), İstanbul 2015. 
Pamuk, Şevket, Osmanlı-Türkizye İktisadî Taribi, 1500-1914, İstanbul 2005.

Pehlivan, Zozan, "Abandoned Villages in Diyarbekir Province at the End of the 'Little Ice Age', 1800-50", The Ottoman East in the Nineteenth Century: Societies, Identities and Politics, (ed. Tolga Yaşar Cora, Ali Sipahi ve Dzovinar Derderian),. Londra ve New York 2016, s. 223-46.

Quataert, Donald, Osmanl Devleti'nde Avrupa İktisadi Yaynlım ve Direniş (1881-1908), Ankara 1987.

Savaş, Saim, "Osmanlı Döneminde Sivas'ta Tuz Üretimine Dair Bazı Bilgiler", Journal of Ottoman Studies, s. 20 (2000), s. 223-45.

Shaw, Stanford J., History of the Ottoman Empire and Modern Turkey, Cilt 2: Reform, Revolution, and Republic: The Rise of Modern Turkey, 1808-1975, New York 1977.

Tizlak, Fahrettin, "Osmanlı Maden İşletmeciliğinden Kanunnâmeden Nizamnâmeye Geçiş ve 1861 Tarihli Maden Nizamnâmesi", Türk Dünyası Araștırmalar, s. 98 (1995)s. 7591.

"Üretim Bölgeleri Yönünden Karşılaştırma ve Değerlendirme", Bilimsel Madencilik Dergisi, 13/5 (1974), s. 51-55.

Yerasimos, Stefanos, Azggelişmişlik Sürecinde Türkiye, Cilt 2: Tanzimattan I. Dünya Savaşına, İstanbul 1975.

Yılmaz, Fehmi, "Osmanlı İmparatorluğu'nda Tütün: Sosyal, Siyasî Ve Ekonomik Tahlil (1660-1883)", Marmara Üniversitesi, Doktora Tezi, 2005.

Yüksel, Ahmet, "Türkiye'de Tütüncülerin Kaçakçlaşma Sürecinde Kolculuğun Baskısını İki Kolcunun Tercüme-i Halinden Anlama Denemesi", Kebikeę, s. 34 (2012), s. 185-200.

\section{Summary}

This study examines the emergence and evolution of the Ottoman salt monopoly with a particular focus on the salines in the district of Siird. It not only investigates simultaneously the notions of salt and monopoly, understudied themes in the Ottoman historiography, but also conceptualises the socioeconomic dynamics the Ottoman salt monopoly brought about in Siird before the Ottoman Public Debt Administration era. Entertaining the notion of the salt monopoly as a means of fiscalised consumption, the present study argues that the legal and military measures the Ottoman salt monopoly took juxtaposed with the transformation of salt into an item of indirect tax led to a modern episode of modern violence and poverty in the greater Siird region. In this context, this study first sheds light on the establishment of the Ottoman salt monopoly in 1862. Underlining the Ottoman finance officials' urgent needs to finance the foreign debt volumes of which increased enormously from 1855 onwards, it deals with the political and economic considerations underlying the transfer of salines from tax farmers, who were mostly the great merchants and creditors in the Ottoman capital. While several Ottoman councils discussed the economic prospects of the salt monopoly, the Salt Regulation of 1862 laid out the general principles of the administration ranging from the administration, personnel and sale activity of the salt. Juxtaposing the articles of the 
regulation with the later measures the Ottoman officials devised to maintain a more profitable monopoly this section also deals with the salt prices the Ottoman monopoly authorities occasionally increased depending on the urgent needs of financing the foreign debt.

In the next section, the present study focuses on the salines of Siird after the establishment of the salt monopoly. Compiling available data regarding production and employment capacities of each saline in Siird, it shifts the focus to the dynamics between the monopoly officials and Kurdish emirs and tribes. Denying entry to the officials, most members of the surrounding Kurdish tribes vehemently opposed the takeover of salines by the Ottoman government. Dealing on one hand with the measures the Ottoman government took to consolidate the operations of the monopoly administration in the salines of Siird and particular cases in which Kurdish emirs supporter by the Kurdish tribes assaulted salines and stole salt on the other hand, this section investigates the interaction between the Ottoman salt monopoly administrators and Kurdish mirs, who claimed to have possessed the salines in question. In this confrontation, it was the Ottoman government that changed the means of intervention, resorting to frequent military operations for the control, operation, and protection of the salines. However, the interaction was not oppositional with episodes of violence. Rather, as this section demonstrates, the salt monopoly at times delegated the administration of the salines to a few local Kurdish powerholders, with the obvious aim to co-opt the local Kurdish emirs spearheading the resistance in the monopoly administration. While this section focuses on the episodes of interaction between the salt monopoly and the Kurdish emirs and tribes, it also elucidates the new legislation the Ottoman government concluded for a more profitable administration of the monopoly.

In the last section, this study deals with the immediate consequences of the Ottoman salt monopoly in the district of Siird. Associating these consequences with the transformation of a necessity good into an item of indirect tax, this section underlines the socioeconomic results the salt monopoly brought about in Siird. As one of these results, this section differentiates the smuggling of salt compared to smuggling of grains and tobacco in the earlier eras. Then it proceeds to poverty, another result of the salt monopoly. In a similar vein, this study notes the difference of sale of salt before the era of monopoly and claims that the sale of salt after the establishment of the monopoly served primarily to finance the foreign debts at the expense of domestic consumers. Apart from the perspective of consumers, the salt monopoly also contributed to, however limited, proletarianization of the salt workers who had received their wages in kind depending on the salt they had extracted. That is, the monopoly administration, with the evident threat of workers selling salt in the Ottoman markets freely, turned these workers into wage-earners, who became yet another group among salt consumers losing their traditional shares of salt due to their labours. In line with these transformations, the successive increases in salt price, the present study demonstrates, not only made poverty visible in a "modern" sense, but also prompted incentives for salt 


\section{Uğur Bayraktar}

smuggling. In this context, the present study argues that it was not Ottoman Public Debt Administration that turned the Ottoman subjects into agents of "imperialist" ventures, but rather the Ottoman salt monopoly preceded it much earlier. 